\title{
Generation of Intracellular Reactive Oxygen Species and Genotoxicity Effect to Exposure of Nanosized Polyamidoamine (PAMAM) Dendrimers in PLHC-1 Cells in Vitro
}

\author{
Hugh Byrne \\ Technological University Dublin, hugh.byrne@tudublin.ie \\ Pratap Naha \\ Technological University Dublin
}

Follow this and additional works at: https://arrow.tudublin.ie/nanolart

Part of the Other Pharmacology, Toxicology and Environmental Health Commons, Terrestrial and Aquatic Ecology Commons, and the Toxicology Commons

\section{Recommended Citation}

Byrne, H., Naha, Pratap C.: Generation of Intracellular Reactive Oxygen Species and Genotoxicity Effect to Exposure of Nanosized Polyamidoamine (PAMAM) Dendrimers in PLHC-1 Cells in Vitro. Aquatic Toxicology, 132-133, 61- 72 (2013). doi:10.1016/j.aquatox.2013.01.020

This Article is brought to you for free and open access by the NanoLab at ARROW@TU Dublin. It has been accepted for inclusion in Articles by an authorized administrator of ARROW@TU Dublin. For more information, please contact arrow.admin@tudublin.ie, aisling.coyne@tudublin.ie,gerard.connolly@tudublin.ie. Funder: HEA

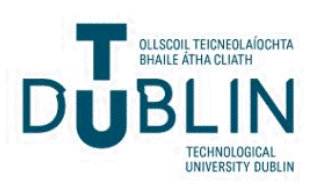


Generation of intracellular reactive oxygen species and genotoxicity effect to exposure of nanosized polyamidoamine (PAMAM) dendrimers in PLHC1 cells in vitro

\section{Pratap C. Naha ${ }^{a b^{*}}$ and Hugh J. Byrne ${ }^{\mathrm{b}}$}

${ }^{a}$ Radiation and Environmental Science Centre, Focas Research Institute, Dublin Institute of Technology, Kevin Street, Dublin 8, Ireland, and Dept. of Radiology, Perelman School of Medicine, University of Pennsylvania, Philadelphia, PA-19104, USA.

${ }^{b}$ NanoLab, Focas Research Institute, Dublin Institute of Technology, Kevin Street, Dublin 8, Ireland.

*Corresponding Authors

Pratap C. Naha,

Dept. of Radiology

Perelman School of Medicine

University of Pennsylvania

Philadelphia-19104

USA

E mail: Pratap.Naha@uphs.upenn.edu

Phone: Tel: +1-215-746-1383 


\begin{abstract}
Polyamidoamine (PAMAM) dendrimers elicit systematically variable cyto- and ecotoxic responses, promising the basis for structure activity relationships governing nanotoxicological responses. Increased production of intracellular reactive oxygen species (ROS), genotoxicity and apoptosis due to in-vitro exposure of hepatocellular carcinoma cells to dendrimer generations G-4, G-5 and G-6 is demonstrated. A generation dependent increase in ROS and genotoxicity was observed, consistent with our previous studies. The responses correlate well with the number of surface amino groups per generation. Although ROS production initially increases approximately linearly, it saturates at higher doses. Notably, normalised to molar dose of surface amino groups, the dose-dependent ROS production for different generations overlap exactly, indicating that the response is due to these functional units. The percentage tail DNA formation is related to the generation and dose dependent production of intracellular ROS, at low levels. At the higher ROS levels, increased DNA damage is associated with the onset of necrosis.
\end{abstract}

Key words: Nanotoxicology, Hepatocellular carcinoma cells, PAMAM dendrimers, ROS, Cytotoxicity, Genotoxicity. 


\section{Introduction}

The ecological impact of increased exploitation of nanotechnologies and resultant release of nanoparticles is of growing concern. However, given the range of nanoparticle types, physico-chemical properties and potential exposure scenarios, it is difficult to establish the basis for appropriate risk assessment (Handy et al., 2012). In this context, similar to the case of human exposure, a fundamental understanding and quantification of the structural dependence of biological responses is paramount, highlighting the importance of systematic studies upon which such quantitative structure activity relationships (QSARS) for nanomaterials might be established. Our previous study of $\mathrm{N}$-isopropylacrylamide/N-tert-butylacrylamide copolymer nanoparticles demonstrated a clear relationship between the observed toxicity in a range of fresh water test models, representing different trophic levels, and the physico-chemical properties of the nanoparticles (Naha et al., 2009a). Similarly, clear structural dependences of the cytotoxic responses of all trophic levels have been observed with nano-sized Polyamidoamine (PAMAM) dendrimers in the same range of fresh water ecological organisms and fish cell-lines (Naha et al., 2009b).

PAMAM dendrimers contain a 2-carbon ethylenediamine core and primary amino groups at the surface (http://www.dendritech.com/pamam.html), and this structural architecture of PAMAM dendrimers make it an attractive option for drug delivery and other biomedical applications (Venuganti and Perumal 2008; Svenson and Tamalia 2005; Emanuele and Attwood 2005; Ducan and Izoo 2005)

Notably, however, there are several reports of mammalian toxicity of PAMAM dendrimers. They have been shown to reduce the transmembrane potential and hinder the influx of $\mathrm{Ca}^{2+}$ ions to the mitochondria (Labieniec and Gabryelak 2008). 
Mitochondrial $\mathrm{Ca}^{2+}$ overload in combination with oxidative stress and ATP depletion induces mitochondrial permeability which results in ischemia reperfusion, oxidative stress and apoptosis (Vergun and Reynolds, 2005). The toxicity of PAMAM dendrimers in mammalian cells has been demonstrated to depend upon the generation and surface functional groups (Roberts et al., 1996; Malik et al., 2000, Mukherjee 2010a). They have been shown to induce membrane disruption, including the formation of holes and membrane erosion in supported lipid bilayers (Leroueil et al., 2007 and 2008; Hong et al., 2004). A recent study shows that the pathway of the toxic response induced by PAMAM dendrimers is by apoptosis mediated by mitochondrial dysfunction. (Lee et al., 2009) and the critical role of intracellular Reactive Oxygen Species (ROS) in this process has been highlighted (Naha et al., 2010a, Mukherjee et al., 2010 b).

Oxidative stress has been established as one of the key factors determining the toxicity of several nanomaterials (Nel et al., 2006; Lanone et al., 2006; Donaldson et al., 2006; Obedoster et al., 2005). Free radical formation causes damage to biological components through oxidation of lipids, proteins and DNA damage and finally leads to apoptotic or necrotic cell death. However, there is a range of ROS which can be generated, dependent upon the chemical nature of the toxicant. Also different species of ROS lead to different intracellular responses. For example, the hydroxyl radical can lead to adduct formation in the base pairs of DNA such as 8-OHdG (8-hydroxy2'deoxyguanosine) production, which mediates the pathophysiology of a wide variety of diseases including cancer, atherosclerosis, neurodegenerative disorders and the aging process (Halliwell and Gutteridge, 1999). Because of its importance, the potential of nanoparticles to elicit such a response should be investigated. 
Systematically varied molecular nanostructures such as PAMAM dendrimers present a route towards an understanding of the dependence of the interactions with bio systems on the physico-chemical properties of nanomaterials. As well as their potential importance in nanomedical applications, the structurally well-defined and variable macromolecules can also provide a further basis upon which to establish structure activity relationships governing eco-toxicological responses which may serve to develop a fundamental understanding of their interactions (Naha et al., 2009b).

The PLHC-1 cell line, derived from a hepatocellular carcinoma in an adult female topminnow (Poeciliopsis lucida), was employed to represent vertebrate models, in accordance with the EU policy of Reduction, Replacement and Refinement (RRR), (Directive 2010/63/EU) for the protection of animals used for experimental and scientific purposes. In a previous study, within a multitrophic battery of test models, the PLHC-1 cell line was seen to be the most sensitive cellular assay and a clear and systematic dependence of the toxic response on the dendrimer generation was observed (Naha et al., 2009b). In this paper, the mechanism of the toxicity pathway of PAMAM dendrimers is further explored in the PLHC-1 cell line. Analysis of the generation of reactive oxygen species, DNA damage and apoptosis was performed to understand the cell death process.

\section{Materials and methods}

\subsection{Materials}

Polyamidoamine (PAMAM) dendrimers, G4, G5 and G6, were purchased from Sigma Aldrich Ltd. (Dublin, Ireland). All generations have an ethylenediamine core and 
PAMAM G4, G5 and G6 have respectively 64, 128 and 256 functional primary amino groups on the surface. The molecular weights of G4, G5 and G6 are 14,215 Da, 28,826 Da and 58,048 Da respectively. The nominal diameters of the G4, G5 and G6 dendrimers are 4.5, 5.4 and $6.7 \mathrm{~nm}$ respectively (www.dendritech.com). The diameters and zeta potentials of the dendrimers were measured using a Malvern Zeta Sizer Nano ZS (Malvern Instruments, Worcestershire, UK). The measurements were performed on $20 \mu \mathrm{M}$ dendrimer solutions in cell culture media at $24^{\circ} \mathrm{C}$ (Naha et al., 2009b).

\subsection{Reagents}

Alamar Blue (AB) was purchased from Biosource (UK). Cell culture media (DMEM, D5546), LMP agarose, comet assay reagents and Ethyl-N-nitrosourea (ENU), were purchased from Sigma Aldrich Ltd. (Dublin, Ireland). 5-(and 6) Carboxy-2',7'dichloro-dihydroflourescein diacetate $\left(\mathrm{H}_{2} \mathrm{DCFDA}\right)$ and the apoptosis assay kit were purchased from Invitrogen. The $8-\mathrm{OHdG}$ assay was purchased from Wako Pure Chemicals Industries, Ltd, Osaka, Japan. SYBR $^{\circledR}$ Green and GelBond ${ }^{\circledR}$ films were purchased from Lonza (Rockland, USA). Lab- Tek ${ }^{\circledR}$ Chamber Slides $^{\mathrm{TM}}$ were purchased from Nalge Nunc International.

\subsection{Cell Culture}

PLHC-1 cells (CRL-2406) were obtained from the American Type Culture Collection. Cells were maintained in DMEM supplemented with $5 \% \mathrm{FCS}, 45 \mathrm{IU} \mathrm{ml}^{-1}$ penicillin, and $45 \mu \mathrm{g} \mathrm{ml}^{-1}$ streptomycin. Cultures were maintained in a refrigerated incubator (Leec, Nottingham, UK) at a temperature of $30^{\circ} \mathrm{C}$ under normoxic atmosphere. For 
subculture, the cells were detached using Versine/trypsin solution (1 mM EDTA/0.25 $\%$ trypsin) in $\mathrm{Ca}^{2+}$ and $\mathrm{Mg}^{2+}$ free Hanks Balanced Salts Solution (HBSS).

\subsection{Preparation of Dendrimer solutions}

Dendrimer test solutions were prepared in the cell culture media. They were soluble in the media at $37{ }^{\circ} \mathrm{C}$ and were dispersed uniformly by low speed vortex. PAMAM dendrimers solutions were prepared from 0.15 to $6 \mu \mathrm{M}$ for the ROS study, 0.125 to 1 $\mu \mathrm{M}$ for the genotoxicity assay, and $0.5 \mu \mathrm{M}$ for the study of $8-\mathrm{OHdG}$. In the case of the apoptosis assay, concentration ranges of 0.65 to $5.2 \mu \mathrm{M}, 0.25$ to $2 \mu \mathrm{M}$ and 0.15 to $1.2 \mu \mathrm{M}$ were employed for G4, G5 and G6 respectively.

\subsection{Cytotoxicity assay}

Details of particle characterisation and cytotoxicity protocols are described in the supporting information.

\subsection{Intracellular Reactive Oxygen Species (ROS)}

Intracellular reactive oxygen species were measured by a fluorometric assay using Carboxy $\mathrm{H}_{2}$ DCFDA [5 (and-6)-Carboxy-2', 7'-dichloro-dihydroflourescein diacetate)] as the probe (http://probes.invitrogen.com). Carboxy $\mathrm{H}_{2}$ DCFDA was used because it carries an additional negative charge that improves its retention compared to noncarboxylated forms (http://probes.invitrogen.com/media/pis/g002.pdf). Intracellular oxidation of (6-carboxy-2',7'-dichlorodihydrofluorescein diacetate (Carboxy $\mathrm{H}_{2}$ DCFDA) to 2', 7'-di-chlorofluorescein (DCF) was monitored according to the 
increase in fluorescence, as measured by a plate reader and using confocal fluorescence microscopy.

In brief, the assay was performed in black 96 well microplates (Nunc, Denmark). The PLHC-1 cells were seeded in $100 \mu \mathrm{l}$ of cell suspension in each well at a density of $8 \mathrm{x}$ $10^{5}$ cells $/ \mathrm{ml}$. After $24 \mathrm{~h}$ of cell attachment, plates were washed with $100 \mu \mathrm{l} /$ well PBS and the cells were treated with increasing concentrations, from 0.15 to $6 \mu \mathrm{M}$, for each generation of PAMAM dendrimer, prepared in 5\% FCS containing media. Hydrogen peroxide $(400 \mu \mathrm{M})$ was used as positive control to validate the protocol. All incubations were performed at $30^{\circ} \mathrm{C}$ in an incubator. Six replicate wells were used for each control and test concentrations per each individual experiments. After the specified incubation time period $(1,2,4,6$ and $12 \mathrm{~h})$, the plates were washed with 100 $\mu \mathrm{l} /$ well PBS and then $100 \mu \mathrm{l} /$ well of $10 \mu \mathrm{M}$ Carboxy $\mathrm{H}_{2}$ DCFDA was added to each well. The plates were incubated at $30^{\circ} \mathrm{C}$ for a period of 40 mins. The optimal loading time for the Carboxyl $\mathrm{H}_{2}$ DCFDA was determined according to a kinetic study of the response to $\mathrm{H}_{2} \mathrm{O}_{2}$ as a positive control. This time point was found to be substantially below the saturation point of the assay for exposure to $400 \mu \mathrm{M} \mathrm{H}_{2} \mathrm{O}_{2}$. Thus increases in ROS levels as a result of nanoparticle exposure to this level and beyond can be measured.

The fluorescence was quantified using a plate reader, which provides an average of the statistically variable response of individual cells (Elbekai and El-Kadi, 2005). Fluorescence was measured using an excitation of $485 \mathrm{~nm}$ and emission of 530nm, in a TECAN GENios (Grodig, Austria) microplate reader. For visualisation of the intracellular fluorescence, carboxy $\mathrm{H}_{2}$ DCFDA was excited at $488 \mathrm{~nm}$ and 
fluorescence emission at $520 \mathrm{~nm}$ (with a $505 \mathrm{~nm}$ long pass filter) was recorded using a confocal laser scanning microscope (LSM 510 META, Zeiss, Germany). Imaging was performed using a x63 oil immersion objective. Fluorescence and phase contrast images were recorded from a minimum of 3 areas per sample.

\subsection{Alkaline Comet assay}

The alkaline comet assay, also known as single cell gel electrophoresis (SCGE), is a rapid and sensitive technique for analysis and quantification of DNA damage in individual living cells. It probes damage such as single and double strand breaks and alkali-labile sites. Individual cells are embedded in a thin agarose gel on a microscope slide. All cellular proteins are then removed from the cells by lysing and the DNA is then allowed to denature under alkaline/neutral conditions. Under an applied voltage, damaged DNA or DNA fragments migrate and thus the process produces an image with a pronounced head and tail, resembling a comet. The head consists of remaining undamaged DNA, while the tail consists of damaged (single stranded or double stranded breaks) or fragments of DNA. The gel is analysed for fluorescence in the head and tail and the length of tail. The extent of DNA liberated from the head of the comet is directly proportional to the amount of DNA damage.

The genotoxic response of PLHC-1 cells to PAMAM dendrimer exposure was assessed using the micro-comet assay technique. For a typical experiment, $100 \mu \mathrm{l}$ of $1 \times 10^{5}$ cells $/ \mathrm{ml}$ were seeded for 6,12 and $24 \mathrm{~h}$ experiments in a 96 well plate and incubated at $30^{\circ} \mathrm{C}$ for 24 hours to ensure cell attachment. The cell monolayers were then washed with PBS and exposed to varying particle concentrations of PAMAM dendrimers $(0.1250 .25,0.5,0.75$ and $1 \mu \mathrm{M})$ of G4, G5 and G6 for 6, 12 and 24h. 
After the appropriate exposure time, cells were washed once with PBS, trypsinized and suspended in low melting point agarose and cast onto a gel bond film fixed with chamber slides. After the agarose solidified, it was suspended in freshly prepared and pre-cooled cell lysis buffer for $6 \mathrm{~h}$. Electrophoresis was conducted in alkaline electrophoresis buffer ( $\mathrm{pH}$ 12.7) for 15 mins (conditions: $300 \mathrm{~mA}, 1.5 \mathrm{~V} / \mathrm{cm}$ at $4^{\circ} \mathrm{C}$ ). After completion of the electrophoresis run time, the Gelbond ${ }^{\mathrm{TM}}$ film was treated with neutralisation buffer ( $\mathrm{pH}$ 7.5) for 30 mins to neutralise the DNA embedded gels and then dehydrated in absolute ethanol for $2 \mathrm{~h}$. Gels were stored in the dark overnight at $4^{\circ} \mathrm{C}$, allowed to dry completely, and were then stained with SYBR-Green nucleic acid stain. Image analysis was performed using Komet 5.5 software (ANDOR $\left.{ }^{\mathrm{TM}}, \mathrm{UK}\right)$ and a Nikon Eclipse E600 microscope attached to a CCD camera. 50 comets were imaged per slide and 4 slides per concentration were prepared. Three independent experiments were performed. Values of percentage tail DNA were automatically calculated by the software. Ethyl Nitrosourea (ENU) $100 \mu \mathrm{M}$ was used as a positive control to validate the experimental protocol.

\subsection{Measurement of 8-OHdG (8-hydroxy, 2' deoxyguanosine) by ELISA}

The 8-OHdG ELISA kit is a competitive in vitro enzyme linked immuno-sorbent assay for quantitative measurement of the oxidative DNA adduct 8-hydroxy, 2' deoxyguanosine (8-OHdG). All reagents and samples were equilibrated to room temperature before use $\left(20-25^{\circ} \mathrm{C}\right)$. The ELISA was carried out according to the manufacturer's instructions (Wako Pure Chemicals Industries, Ltd, Osaka, Japan). In brief, the primary antibody was reconstituted with the primary antibody solution and allowed to dissolve completely. Fifty microlitres of sample (extracted DNA) or standard were added per well, and then $50 \mu 1$ of reconstituted primary antibody were 
added per well. The plate was shaken from side to side and the solution mixed fully. The container was covered with adhesive strip, making sure it was sealed tightly, and incubated at $4{ }^{\circ} \mathrm{C}$ overnight. The contents of the plate were removed. $250 \mu \mathrm{l}$ of washing solution were pipetted into each well. After washing thoroughly by shaking the plate from side to side, the washing solution was removed. The plate was inverted and blotted using a clean paper towel to remove any remaining washing buffer. The washing process was repeated twice more.

The secondary antibody was reconstituted with the secondary antibody solution. 100 $\mu \mathrm{l}$ of constituted secondary antibody were added per well. The plate was shaken from side to side to mix fully. The plate was covered with an adhesive strip and incubated at room temperature for 1 hour. At the end of the incubation period, the plates were washed twice with washing buffer. The chromatic solution (enzyme substrate solution) was reconstituted with 100 times the volume of the diluting solution. $100 \mu \mathrm{l}$ of the reconstituted enzyme substrate were added per well. The plate was shaken from side to side to mix fully and was incubated at room temperature for 15 mins in the dark. $100 \mu \mathrm{l}$ of the reaction terminating solution were added per well. The plate was shaken from side to side to mix fully. After terminating the reaction, the absorbance at $450 \mathrm{~nm}$ was measured.

\subsection{Apoptosis assay}

Apoptosis is a programmed cell death process, during which the cytoplasmic membrane increases slightly in permeability. The increase of apoptosis induced cell death as a result of exposure to nanoparticles was investigated by using a kit containing both YO-PRO®-1 and PI dyes. YO-PRO ${ }^{\circledR}-1$ is a green fluorescent dye which can enter apoptotic cells. Propidium iodide (PI), a red fluorescent dye, on the 
other hand cannot enter into the cells. When employed in parallel, they provide a sensitive indicator for apoptosis (Idziorek et al., 1995; Estaquier et al., 1996). After incubation of a cell population with $\mathrm{YOPRO}^{\circledR}-1$ and PI, apoptotic cells show green fluorescence, necrotic cells/dead cells show red and green fluorescence, and no fluorescence is from live cells, (http://probes.invitrogen.com/media/pis/mp13243.pdf.). The PLHC-1 cells were plated in a 6 well plate at a seeding density of $1 \times 10^{6}$ cells $/ \mathrm{ml}$ well. The plates were incubated at $30{ }^{\circ} \mathrm{C}$ for 24 hour to ensure proper attachment. The cell monolayer was washed with PBS and then exposed to a range of concentrations of PAMAM dendrimers (G4, G5 and G6) for different time points (6, 12 and 24h). After the appropriate exposure time, cells were washed once with PBS, trypsinized, centrifuged, the supernatant removed and then the cell pellets were suspended in $1 \mathrm{ml}$ PBS. $1 \mu 1$ of YO-PRO®- 1 dye and $1 \mu \mathrm{l}$ PI were added to the cell suspension and it was incubated on ice for 30 mins. After the incubation time, the fluorescence of the cell suspension was measured in a flow cytometer (Partec CyFlow ${ }^{\circledR}$ space). The experimental protocol was validated by using camptothecin as positive control.

\subsection{Statistics}

All experiments were conducted in at least triplicate (three independent experiments). The levels of intracellular ROS were expressed as mean percentage inhibition relative to the unexposed control \pm standard deviation $(\mathrm{SD})$. The genotoxicity assay was performed on four replicates per concentration and three independent experiments. The genotoxicity response was expressed in terms of percentage tail DNA as the mean percentage \pm standard deviation (SD). The distributions of the data were checked and 
found to be normal and thus the data is deemed to be suitable for analysis using one way analyses of variance, ANOVA, which were followed by Dunnett's multiple comparison tests. Statistical significance was accepted at $P \leq 0.05$ for all tests. Toxicity data was fitted to a sigmoidal curve and a four parameter logistic model used to calculate $\mathrm{EC} / \mathrm{LC}_{50}$ values. This analysis was preformed using Xlfit3 ${ }^{\mathrm{TM}}$ a curve fitting add-in for Microsoft ${ }^{\circledR}$ Excel (ID Business Solutions, UK).

\section{Results}

\subsection{Particle characterization and Cytotoxicity}

Particle characterisation in terms of hydrodynamic diameter and zeta potential of PAMAM dendrimers of all generations in the cell culture media is presented in the supporting information (Table S1). Cytotoxicity data, as reported in Naha et al., $2009 \mathrm{~b}$, are summarised in figure S1. Figure 1 demonstrates the clear dependence of the measured cytotoxicity, expressed in terms of inverse $\mathrm{EC}_{50}$, on the generation number and structure, as represented by the number of surface amino groups (Figure 1).

\subsection{Intracellular reactive oxygen species $(\mathrm{ROS})$}

Quantitative measurement of the intracellular ROS generation in PLHC-1 cells was performed at different time points $(1 \mathrm{~h}, 2 \mathrm{~h}, 4 \mathrm{~h}, 6 \mathrm{~h}$ and $12 \mathrm{~h})$ and with different exposure concentrations of each dendrimer (G4, G5 and G6). For all generations, the exposure time points and the concentration of PAMAM dendrimer $(0.15 \mu \mathrm{M}$ to $6 \mu \mathrm{M})$ used were the same, in order to correlate intracellular ROS production by the three generations of PAMAM dendrimers and also to enable comparison with the cytotoxic 
and genotoxic responses, as well as apoptosis and cell death. Intracellular ROS generation in PLHC-1 cells upon the exposure to PAMAM dendrimers was visualised using confocal fluorescence microscopy, as shown in figure 2, for the case of $2 \mathrm{~h}$ exposure of each dendrimer, G4 (C), G5(D) and G6 (E) at a concentration of $2 \mu \mathrm{M}$ and $400 \mu \mathrm{M}$ for $\mathrm{H}_{2} \mathrm{O}_{2}$ (B), compared to control (A). It should be noted that the regions of white coloration are present in the control samples and therefore are not the due to nanoparticles, but may be due to the reflection of the white light.

Intracellular ROS production was found to be dendrimer generation, dose and time dependent. The time evolution of the ROS response for all three generations is shown in figure 3 , for a dose of $0.6 \mu \mathrm{M}$ for each generation. For each generation, the increase in ROS levels increases initially, reaches a maximum at 2-4hrs before decreasing with further exposure time. A significant generation dependent ROS production G6 > G5 > G4 was observed at 1,2 , and $12 \mathrm{~h}$ exposure time period $(\mathrm{p} \leq 0.05)$.

The concentration dependent increase in ROS production for the five different time points for the three dendrimer generations was monitored using the fluorescence plate reader and the results are shown in figure 4 . At the lower concentrations, exposure results in a monotonic increase in the intracellular ROS production at all time points. At higher concentrations, a saturation of ROS production was observed (figure 4). For all PAMAM generations (G4, G5 and G6) the maximum level of ROS production is approximately $90 \%$ and this maximum level is reached after $\sim 2 \mathrm{~h}$ for G5 and G6, while for the case of G4, the maximum level is reached at $\sim 4 \mathrm{~h}$. The generation of ROS is counteracted by the natural intracellular antioxidants which act to minimize the oxidative stress (Sies, 1993). 
Figure 5A describes the relationship between the intracellular ROS production and the number of primary surface amino groups of the PAMAM dendrimer generation for a fixed concentration of $0.6 \mu \mathrm{M}$ at $2 \mathrm{~h}$ exposure time. Similar to the case of the cytotoxic response, the generation dependent ROS levels appear to be correlated with increasing generation, following the trend of G6 > G5 > G4 as shown in figure 3. This trend mirrors that of the cytotoxic response (Figure 1).

The intracellular ROS production in PLHC1 cells is systematically dependent on generation and concentration of PAMAM dendrimers. In general, the time evolution of the ROS is not very well understood, but similar behaviour has been observed in other studies (Mukherjee et al., 2010b). A more recent study has demonstrated that generation, dose and time dependence of the ROS production and subsequent cellular responses can be simulated using a simple rate equation approach, whereby a single variable representing the rate of generation of reactive oxygen species, linearly dependent on the number of surface amino groups per generation. (Mukherjee et al., 2012). Notably, when the concentration is expressed in terms of effective number of amino groups (molar dose $\mathrm{x}$ number of amino groups per dendrimer), the ROS generation curves for a fixed time point overlap almost exactly, as shown in figure 5B. This is further indication that their number of surface amino groups is the primary source of the toxicity of PAMAM nanoparticles.

\subsection{Genotoxicity response of PAMAM dendrimers}

The genotoxicity of the PAMAM dendrimers was evaluated in PLHC-1 cells over a concentration range from $0.125 \mu \mathrm{M}$ to $1 \mu \mathrm{M}$ for the cases of G4, G5 and G6, for different exposure times $(6 \mathrm{~h}, 12 \mathrm{~h}$ and $24 \mathrm{~h})$. For all dendrimer generations, the 
concentration range is one of approximately linear increase in levels of ROS (figure 4). DNA damage was estimated by analyzing the tail percentage DNA in the comet assay. Representative micrographs of observed comets are shown in figure 6, after 24 hour exposure to PAMAM dendrimers at a concentration of $0.5 \mu \mathrm{M}$. A dose dependent genotoxicity response was observed for all three generations of PAMAM dendrimers in PLHC-1 cells (Figure 7). Significant genotoxicity response was observed in PLHC-1 cells as compared to control group $(\mathrm{p} \leq 0.05)$ after exposure of PAMAM dendrimers. A generation dependent level of DNA damage was also observed (Figure 8). Significant generation dependent $(\mathrm{p} \leq 0.05)$ genotoxicity response was observed at 24 hour exposure time period. After 6 and $12 \mathrm{~h}$ exposure, a significant difference of genotoxicity response between G4, G6, and between G5, G6 $(\mathrm{p} \leq 0.05)$ is observed at a concentration of $0.5 \mu \mathrm{M}$ (Figure 8).

In our previous study, the toxic responses of all organisms studied were well correlated with the physico-chemical characteristics of the PAMAM dendrimers (Naha et al., 2009), and here the same is observed for the generation of intracellular ROS and the genotoxic response in PLHC-1 cells, indicating that the paradigm of oxidative stress as the source of the toxic mechanism of nanoparticles, outlined by $\mathrm{Nel}$ et al., 2006, is applicable for PAMAM dendrimers. Notably, both the oxidative stress and the genotoxic response are correlated with the number of surface amino groups per dendrimer as shown in figures $5 \mathrm{~A}$ and 9.

\subsection{8-OHdG assay}

Oxidative damage to DNA in cells by ROS is a well reported process (Zhang et al., 2009), which is associated with the pathophysiology of a wide variety of diseases 
including cancer, atherosclerosis, neurodegenerative disorders and the aging process in general (Halliwell and Gutteridge, 1999). The level of oxidative DNA adduct 8hydroxy-2'-deoxyguanosine the 8-OHdG (8-hydroxy2'-deoxyguanosine) production in PLHC-1 cells as a result of PAMAM exposure was measured by a competitive in vitro enzyme-linked immunosorbant assay. As significant genotoxicity and intracellular ROS response was observed at $0.5 \mu \mathrm{M}$, this concentration was used for the detection of $8-\mathrm{OHdG}$ formation. The exposure concentration used was $0.5 \mu \mathrm{M}$ of G4, G5 and G6, each at $6 \mathrm{~h}, 12 \mathrm{~h}$ and $24 \mathrm{~h}$ time periods. The results are presented in Table S2. Notably, there is no significant difference between the control group and the PAMAM exposure group under any exposure condition. However, there is a significant difference in the level of $8-\mathrm{OHdG}$ production upon exposure to the positive control, $\mathrm{H}_{2} \mathrm{O}_{2}$ (Shown in table $\mathrm{S} 2$ ). No increase in levels of $8-\mathrm{OHdG}$ production upon the exposure to PAMAM dendrimers was detectable over the exposure time period examined. Although a significant degree of DNA damage has been observed as compared to the control group $(\mathrm{p} \leq 0.05)$ at lower concentrations of $0.125 \mu \mathrm{M}, 0.25 \mu \mathrm{M}$ and $0.5 \mu \mathrm{M}$ after $24 \mathrm{~h}$ exposure (figure 6), no 8-OHdG formation was observed at a concentration of $0.5 \mu \mathrm{M}$ at the same time of exposure. Further studies are required to explore the other species of ROS generated which lead to genotoxicity and cell death.

\subsection{Apoptosis Assay}

The apoptosis study performed with PLHC-1 cells exposed to PAMAM G4, G5 and G6 dendrimers illustrated that, with increasing concentration, the percentage of healthy cells decreases, whereas the early apoptotic, late apoptotic and dead cell 
populations increase, as shown in Tables 1,2 and 3 for $6 \mathrm{~h}, 12 \mathrm{~h}$ and $24 \mathrm{~h}$ exposure respectively. After 6 hour exposure, a significant early apoptotic cell population was observed as compared to control groups. A significant difference $(\mathrm{p}<0.05)$ of early apoptotic cell population at exposure concentrations of 0.6 and $1.2 \mu \mathrm{M}$ in the case of G6 and $2 \mu \mathrm{M}$ in the case of G5 as compared to control has been observed. However, a significant $(\mathrm{p}<0.05)$ late apoptotic cell population was observed at all the exposure concentrations, except $0.65 \mu \mathrm{M}$ of G4 after $6 \mathrm{~h}$ exposure (Table 1). After 12 hour exposure to PAMAM dendrimers, significant $(\mathrm{p}<0.05)$ early and late apoptotic cell populations were observed in PLHC- 1 cells except at a $0.65 \mu \mathrm{M}$ concentration of G4, as compared to control (Table 2). However, after 24 hour exposure, all the exposure concentrations of PAMAM dendrimer (G4, G5 and G6) employed show significant $(\mathrm{p}<0.05)$ early and late apoptotic cell populations, as compared with the control group (Table 3). No significant difference between response to the G4, G5 and G6 PAMAM dendrimers was observed at 6 and $12 \mathrm{~h}$ (Figure $10 \mathrm{~A}$ and B), although a significant difference $(\mathrm{p}<0.05)$ in early and late apoptotic cell populations was observed between G4 and G6 at 24 hour exposure (Figure 10 C). Furthermore, a significant difference $(p<0.05)$ is observed between the late apoptotic cell population after 24 hour exposure to G5 and G6 dendrimers (Figure $10 \mathrm{C}$ ).

\section{Discussion}

The surface chemistry of the PAMAM dendrimer series is the same for each generation, but in successive generations, there is a systematic increase in molecular weight, particle size and notably number of surface amino groups per particle. The toxicity also increases systematically with increasing generation of PAMAM 
dendrimer (G6 > G5 > G4) and the response is well correlated with the number of surface primary amino groups (Figure 1), which points towards the importance of the physico-chemical properties as well as underlying structure activity relationships.

The increase in levels of intracellular ROS by PAMAM dendrimers is clearly one of the most relevant toxic pathways and a clear generation dependence of increased intracellular ROS production is shown in figure 3 . The sequence of increased ROS generation is G6> G5 > G4. This response is also dependent on the number of surface primary amino groups of the PAMAM dendrimers, as shown in figure 5A. Indeed, expressing the dose dependence of the ROS generation in terms of number of surface amino groups per exposure, the response to each dendrimer generation overlaps almost exactly. This indicates that the cationic surface amino groups play a direct role in the production of ROS. Increased intracellular ROS generation suggests that the PAMAM dendrimers can lead to disruption of the mitochondrial electron transduction chain which leads to additional $\mathrm{O}_{2}^{-}$production and perturbs the mitochondrial permeability transition pore, which leads to release of pro-apoptotic factors and programmed cell death (Oberdörster et al., 2005). Intracellular ROS production can lead to inflammation, as demonstrated for a number of different nanoparticles (Li et al., 2008; Stone et al., 2007; Lubos et al., 2008; Driscoll, 2000), and potentially also to DNA damage and genotoxicity.

The genotoxicity assessment was performed by alkaline comet assay, which is widely accepted as a simple, sensitive, and rapid tool for assessing DNA damage in different test models and is extensively used for chemical testing (Dhawan et al., 2009) and also for nanoparticles (Naha et al., 2010b; http://www.nanoimpactnet.eu). A significant $(\mathrm{p}<0.05)$ genotoxic response is observed with PAMAM dendrimers as 
compared to control in PLHC-1 cells. The response is systematic and clearly dependent on the generation of the PAMAM dendrimers only at 24h exposure (Figure 8). Similar generation dependent responses to those of the production of ROS and cytotoxicity have been observed. The percentage of DNA damage is clearly dependent upon the number of surface primary amino groups (as shown in Figure 9). As the PAMAM generation increases, there is an increase in the number of surface amino groups (64, 128 and 256 amino groups for G4, G5 and G6 respectively) which makes the particle more cationic. As a result, the observed ROS, DNA damage and cytotoxicity may be considered to be primarily due to the surface amino group. Cationic PAMAM dendrimers have been shown to localise and produce increased levels of ROS initially in endosomes, and later in mitochondria (Mukherjee et al. 2010b, Lee et al., 2009), eliciting a toxic response via oxidative stress and inflammation (Naha et al., 2010a, Mujkerjee et al. 2010b). Of the potential mechanisms of DNA damage as a result of oxidative stress, the production of the oxidative adduct OHdG was explored. No increase in levels of OHdG was found, however, and thus alternative routes such as 2-hydroxyadenin, 8-hydroxyadenine, 4,6diamino-5-form-amidopyrimidine (FapyA), Oxazolone, 2,6-diamino-4-hydroxy-5formamidopyrimidine (FapyG), etc should be explored (Cooke et al., 2003, Kasprzak,K.S. et al.1997, Evans et al., 2004, Tan et al., 1999).

Apoptosis is a programmed cell death mechanism in multicellular organisms (Kerr et al., 1972). It involves a series of biochemical events leading to changes in characteristic cell morphology, including blebbing, changes to the cell membrane, such as loss of membrane asymmetry and attachment, cell shrinkage, nuclear 
fragmentation, chromatin condensation, and chromosomal DNA fragmentation, and finally cell death (Kerr et al., 1972). Apoptosis was detected in cells treated with dendrimers (Table 1 to 3), as measured by FACS (Fluorescence-activated cell sorting) using Yo-Pro® and propidium iodide. It has been reported that a strong interaction between cationic dendrimers and lipid bilayers results in enhanced pore formation (Lee and Larson, 2009). In fact, cationic linear polymers in contact with only a single bilayer do not perforate membranes, whereas the relatively rigid dendrimers penetrate the bilayer, since they can achieve a similar degree of contact between charged groups by interacting with both layers (Lee and Larson, 2009). Thus, perforation by a dendrimer itself could be one of the mechanisms responsible for mitochondrial damage. It has been reported that G5 PAMAM dendrimers induce expression of caspases 3, 9, and Bax proteins and decreased Bcl-2 expression, which is an indication of apoptosis (Lee et al., 2009). The results presented here are consistent with the published literature. After 24 hour exposure, all the exposure concentrations of PAMAM dendrimers (G4, G5 and G6) employed show significant $(\mathrm{p}<0.05)$ early and late apoptotic cell populations as compared with control group (Table 3). No significant difference of early and late apoptotic cell populations between the G4, G5 and G6 PAMAM dendrimers at 6 and $12 \mathrm{~h}$ were observed (Figure $10 \mathrm{~A}$ and B). However, a significant difference $(\mathrm{p}<0.05)$ of early and late apoptotic cell population was observed between G4 and G6 after a 24 hour exposure time period (Figure $10 \mathrm{C}$ ). Notably, an approximately linear dependence of intracellular ROS and genotoxicity response is observed, as presented in figure 11. However, there is saturation of intracellular ROS production at the higher concentrations of PAMAM dendrimers employed in the study. In the apoptosis assay, the percentage of dead cells increases 
with increasing concentration of PAMAM dendrimers. At the higher concentration exposures employed here, the percentages of healthy cells and apoptotic cells are less than at the lower concentration exposure. The cell death induced at the higher concentration exposures employed in this study might therefore be due to necrosis. At the same time, there is a saturation of intracellular ROS production at the higher concentration exposure (Figure 11). Saturation of intracellular ROS production and cell death at higher concentration exposure are well correlated and this may be an indication of necrotic cell death at the higher dose of PAMAM dendrimer exposure in PLHC-1 cells.

\section{Conclusion}

PAMAM dendrimers elicit a significant cytotoxic response in PLHC-1 cells. The generation dependence (G6 > G5 > G4) of the production of increased intracellular ROS, DNA damage and cytotoxicity indicates the direct effects of the positively charged surface amino groups. The toxicity starts with production of reactive oxygen species, which induces DNA damage, apoptosis and finally cell death upon the exposure of PLHC-1 cells to PAMAM dendrimers. As the generation increases, there is an increase in the numer of surface primary amino groups, molecular weight as well as the diameter of the PAMAM dendrimer. The toxic response, in terms of generation of ROS, genotoxicity and cell death, is thus systematically correlated with the systematic variation of the physico-chemical properties of the nanoparticle series. Such systematic relationships may lay the foundation for a fundamental understanding of the nanotoxic responses and ultimately quantitative structure activity relationships. 


\section{Supplementary data description}

Figures and tables in the supporting information were cited in the text as Figure S1 and Table S1. Particle characterisation and cytotoxicity assay protocol is available in supporting information.

\section{Funding}

This work was conducted under the framework of the INSPIRE programme, funded by the Irish Government's Programme for Research in Third Level Institutions, Cycle 4, National Development Plan 2007-2013, supported by the European Union Structural Fund.

\section{Acknowledgement}

We sincerely thank Ms. Amaya Gracia and Prof. Fiona M. Lyng, Focas Research Institute, Dublin Institute of Technology, Dublin, Ireland for assistance with confocal microscopy and FACS.

Declaration of interest: The authors report no conflict of interest. 


\section{References}

Cooke, M.S., Evans, M.D., Dizdaroglu, M., Lunec, J. 2003. Oxidative DNA damage: mechanisms, mutation, and disease. Faseb Journal, 17, 1195-1214.

Dhawan, A., Bajpayee, M., Parmar, D., 2009. Comet assay: a reliable tool for the assessment of DNA damage in different models. Cell Biol. Toxicol. 25, 5-32.

Donaldson, K., Aitken, R., Tran, L., Stone, V., Duffin, R., Forrest, G., Alexaner, A., 2006. Carbon nanotubes: a review of their properties in relation to pulmonary toxicology and work place safety. Toxicol. Sci. 92, 5-22.

Driscoll, K.E. 2000. TNF- $\alpha$ and MIP-2: role in particle induced inflammation and regulation by oxidative stress. Toxicol. Lett. 112-113, 177-184.

Duncan, R., Izzo, L., 2005. Dendrimer biocompatibility and toxicity. Adv. Drug Delivery Rev. 57, 2215-2237.

Elbekai, R.H and El-Kadi, A.O.S., 2005. The role of oxidative stress in the modulation of aryl hydrocarbon receptor-regulated genes by $\mathrm{As}^{3+,} \mathrm{Cd}^{2+,}$ and $\mathrm{Cr}^{6+.}$ Free Radical Biol. Med. 39, 1499-1511.

Emanuele, A.D., Attwood, D., 2005. Dendrimer-drug interactions. Adv. Drug Delivery Rev. 57, 2147-2162.

Evans, M.D., Dizdaroglu, M., Cooke, M.S., 2004. Oxidative DNA damage and disease: induction, repair and significance. Mutat. Res. 567, 1-61.

Handy, R.D., van den Brink, N., Chappell, M., Mühling, M., Behra, R., Dušinská, M., Simpson, P., Ahtiainen, J., Jha, A.N., Seiter, J., Bednar, A., Kennedy, A., Fernandes, T.F., Riediker, M., 2012. Practical considerations for conducting 
ecotoxicity test methods with manufactured nanomaterials: what have we learnt so far? Ecotoxicology DOI 10.1007/s10646-012-0862-y.

Hong, S.P., Bielinska, A.U., Mecke, A., Keszler, B., Beals, J.L., Shi, X.Y., Balogh, L., Orr, B.G., Baker, J.R., Holl, M.M.B., 2004. Interaction of poly(amidoamine) dendrimers with supported lipid bilayers and cells: hole formation and the relation to transport. Bioconjugate Chem. 15, 774-782.

http://www.nanoimpactnet.eu/index.php?page=Researchprotocols. Accessed on 19 March 2011.

http://probes.invitrogen.com/media/pis/mp13243. Accessed on 19 March 2009.

Kasprzak, K.S., Jaruga, P., Zastawny, T.H., North, S.L., Riggs, C.W., Olinski, R., Dizdaroglu, M., 1997. Oxidative DNA base damage and its repair in kidneys and livers of nickel(II)-treated male F344 rats. Carcinogenesis, 18, 271-277.

Kerr, J.F., Wyllie, A.H., Currie, A.R., 1972. Apoptosis: a basic biological phenomenon with wide-ranging implications in tissue kinetics. Br. J. Cancer. 26, 239-257.

Labieniec, M., Gabryelak, T., 2008. Preliminary biological evaluation of Poli(amidoamine) (PAMAM) dendrimer G3.5 on selected parameters of ratliver mitochondria. Mitochondrion, 8, 305-312.

Lanone, S., Boczkowski, J., 2006. Biomedical Applications and Potential Health Risks of Nanomaterials: Molecular Mechanisms. Curr Mol. Med. 6, 651-63.

Lee, H., Larson, R.G., 2009. Multiscale modeling of dendrimers and their interactions with bilayers and polyelectrolytes. Molecules, 19, 423-438. 
Lee, J.H., Cha, K.E., Kim, M.S., Hong, H.W., Chung, D.J., Ryu, G., Myung, H., 2009. Nanosized polyamidoamine (PAMAM) dendrimer-induced apoptosis mediated by mitochondrial dysfunction. Toxicol. Lett. 190, 202-207.

Leroueil, P.R., Hong, S.Y., Mecke, A., Baker, J.R., Orr, B.G., Holl, M.M.B., 2007. Nanoparticle interaction with biological membranes: Does nanotechnology present a janus face? Acc. Chem. Res. 40, 335-342.

Li, N., Xia, T., Nel, A.E., 2008. The role of oxidative stress in ambient particulate Matter-induced lung diseases and its implications in the toxicity of engineered nanoparticles. Free Radical Biol. Med. 44, 1689-1699.

Lubos, E., Handy, D.E., Loscalzo, J., 2008. Role of oxidative stress and nitric oxide in atherothrombosis. Front Biosci. 13, 5323-5344.

Malik, N., Wiwattanapatapee, R., Klopsch, R., Lorenz, K., Frey, H., Weener, J.W., Meijer, E.W., Paulus, W., Duncan, R., 2000. Dendrimers: relationship between structure and biocompatibility in vitro, and preliminary studies in the biodistribution of 125I-labelled polyamidoamine dendrimers in vivo. J. Cont. Rel. 65, 133-148.

Mukherjee, S.P., Davoren, M., Byrne, H.J., 2010a. In vitro mammalian cytotoxicological study of PAMAM dendrimers - towards quantitative structure activity relationships. Toxicol. In Vitro. 24, 169-177.

Mukherjee, S.P., Lyng, F.M., Garcia, A., Davoren, M., Byrne, H.J., 2010b. Mechanistic studies of in vitro cytotoxicity of poly (amidoamine) dendrimers in mammalian cells. Toxicol. Appl. Pharmacol. 248, 259-68. 
Mukherjee, S.P, and Byrne, H.J., 2012. Polyamidoamine Dendrimer Nanoparticle Cytotoxicity, Oxidative Stress, Caspase Activation and Infammatory Response: Experimental Observation and Numerical Simulation. Nanomedicine Nanotechnology Biology and Medicine (In Press).

Naha, P.C., Casey, A., Tenuta, T., Lynch, I., Dawson, K.A., Byrne, H.J., and Davoren, M., 2009a. Preparation, Characterization of NIPAM and NIPAM/BAM Copolymer Nanoparticles and their Acute Toxicity Testing using an Aquatic test battery. Aquat. Toxicol. 92, $146-154$.

Naha, P.C., Davoren, M., Casey, A., Byrne, H.J., 2009b. An ecotoxicological study of poly(amidoamine) dendrimers-toward quantitative structure activity relationships. Environ. Sci. Technol. 43, 6864-6869.

Naha, P.C., Davoren, M., Lyng, F.M., Byrne, H.J., 2010 a. Reactive oxygen species (ROS) induced cytokine production and cytotoxicity of PAMAM dendrimers in J774A.1 cells. Toxicol. Appl Pharmacol. 246, 91-99.

Naha, P.C., Bhattacharya, K., Tenuta, T., Dawson, K. A., Lynch, I., Gracia, A., Lyng, F.M., Byrne, H.J., 2010 b. Intracellular localisation, Geno- and Cytotoxic response of Poly $N$-isopropylacrylamide (PNIPAM) nanoparticles to human keratinocyte (HaCaT) and colon cells (SW 480). Toxicol. Lett. 198, 134-143.

Nel, A., Xia, T., Madler, L., Ning, L., 2006. Toxic potential of materials at nanolevel. Science, 311, 622-627. 
Oberdörster, G., Oberdörster, E., Oberdörster, A., 2005. Nanotoxicology: an emerging discipline evolving from studies of ultrafine particles. Environ. Health Perspect. $113,823-839$.

Park, E.J., Park, K., 2009. Oxidative stress and pro-inflammatory response induced by silica nanoparticles in vitro and in vivo. Toxicol. Lett. 184, 18-25.

Rahman, I., 2000. Regulation of nuclear factor- $\kappa B$, activator protein-1, and glutathione levels by tumor necrosis factor- $\alpha$ and dexamethasone in alveolar epithelial cells, Biochem. Pharmacol. 60, 1041-1049.

Roberts, J.C., Bhalgat, M.K., Zera, R.T., 1996. Preliminary biological evaluation of polyamidoamine (PAMAM) Starburst ${ }^{\mathrm{TM}}$ dendrimers. J. Biomed Material Res. 30, 53-65.

Sies, H., 1993. Strategies of antioxidant defense. Eur. J. Biochem. 215, 213-219.

Stone, V., Johnston, H., Clift, M.J., 2007. Air pollution, ultrafine and nanoparticles toxicology: cellular and molecular interactions. IEEE Trans Nanobiosci. 6, 331-340.

Svenson, S., Tomalia, D.A., 2005. Dendrimers in biomedical applications-reflections on the field. Adv. Drug Delivery Rev. 57, 2106-2129.

Tan, X., Grollman, A.P., Shibutani, S., 1999. Comparison of the mutagenicproperties of 8-oxo-7,8-dihydro-2'-deoxyadenosine and 8-oxo-7,8-dihydro-2'deoxyguanosine DNA lesions in mammalian cells. Carcinogenesis, 20, 22872292.

Venuganti, V.V.K., Perumal, O.P., 2008. Effect of Poly(amidoamine) (PAMAM) dendrimer on skin permeation of 5-fluorouracil. Int. J. Pharm. 361, 230-238. 
Vergun, O., Reynolds, I.J., 2005. Distinct characteristics of Ca2+ induced depolarization of isolated brain and liver mitochondria. Biochim. Biophys. Acta. 1709, 127-137.

Zhang, R., Kang, K.A., Piao, M.J., Maeng, Y.H., Lee, K.H., Chang, W.Y., You, H.J., Kim, J.S., Kang, S.S., Hyun, J.W., 2009. Cellular protection of morin against the oxidative stress induced by hydrogen peroxide, Chem. Biol. Interact. 177, 21-27.

\section{Figure legends}

Figure 1. Relation between number of surface amino group and the toxic response of PAMAM dendrimers at $96 \mathrm{~h}$ exposure. All the data are expressed as mean $\pm S D(n=3)$.

Figure 2. Confocal laser scanning micrograph (CLSM) of PLHC-1 cells showing intracellular ROS production upon exposure to PAMAM dendrimers for $2 \mathrm{~h}$. Figure A, B, C, D and E represent the Negative control, $\mathrm{H}_{2} \mathrm{O}_{2}$, PAMAM G4, G5 and G6 respectively at $2 \mu \mathrm{M}$ concentration for the case of PAMAM and $400 \mu \mathrm{M} \mathrm{H}_{2} \mathrm{O}_{2}$. Magnification is $63 \mathrm{x}$.

Figure 3. The generation and time dependent intracellular ROS production at a concentration of $0.6 \mu \mathrm{M}$. *Denotes significant difference of ROS production between G4, G5 and G6 each exposure time period, 1, 2, and $12 \mathrm{~h}(\mathrm{p} \leq 0.05)$.

Figure 4. Concentration and time dependent intracellular ROS generation, upon exposure to PAMAM dendrimers (A) G4 (B) G5 and (C) G6. The data are presented 
as mean $\pm \mathrm{SD}(\mathrm{n}=3) . \%$ of cell fluorescence as compared to control.Add few lines (methodology)

Figure 5. (A) The relationship between maximum surface amino group and the intracellular ROS production in PLHC-1 cells *Denotes significant difference of ROS production with increasing number of surface primary amino groups $(\mathrm{p} \leq 0.05)$.

Plot showing the relationship between the intracellular ROS production and the molar volume $\mathrm{x}$ no of surface amino groups at 2 hour exposure time period of $0.6 \mu \mathrm{M}$ concentration.

Figure 6. Representative micrographs showing comets of PLHC-1 cells after 24 hour exposure to PAMAM dendrimers. Panel A represents control, Panel B, Represents ENU (Ethyl nitrosourea), Panels C, D and E represent G4, G5 and G6 respectively.

Figure 7. Genotoxicity response of PAMAM dendrimers at $6 \mathrm{~h}, 12 \mathrm{~h}$ and $24 \mathrm{~h}$ exposure, Panels A, B and C represent PAMAM G4, G5 and G6 respectively. *Denotes significant difference in genotoxic response as compared to control group $(p \leq 0.05)$.

Figure 8. Generation dependent genotoxicity response of PAMAM dendrimers at $6 \mathrm{~h}$, $12 \mathrm{~h}$ and $24 \mathrm{~h}$ exposure at $0.5 \mu \mathrm{M}$ concentration. $* * *$ Denotes significant difference of genotoxicity response between $\mathrm{G} 4, \mathrm{G} 5$ and G6 $(\mathrm{p} \leq 0.05)$. ${ }^{* *}$ Denotes significant difference of genotoxicity response between G4, G6, and between G5, G6 ( $p \leq 0.05$ ). 
Figure 9. Relationship between the \% Tail DNA and number of primary surface amino groups of the PAMAM dendrimers $(24 \mathrm{~h}$ exposure at $0.5 \mu \mathrm{M}$ concentration. Data show mean \pm SD.)

Figure 10. Generation dependent apoptosis of the PLHC-1 cells for exposure concentrations of 5.2, 2 and $1.2 \mu \mathrm{M}$ for G4, G5 and G6 respectively. Figure A, B and $\mathrm{C}$ represent $6 \mathrm{~h}, 12 \mathrm{~h}$ and $24 \mathrm{~h}$ exposure respectively. $* *$ Denotes significant difference ( $p \leq 0.05$ ) between G4, G6 and between G5 G6; * denotes significant difference between G4 and G6 ( $\mathrm{p} \leq 0.05)$.

Figure 11. Relationship between maximum DNA damage and maximum intracellular ROS production upon exposure to PAMAM dendrimers G4, G5 and G6. (DNA damage at $24 \mathrm{~h}, \mathrm{ROS}$ at $2 \mathrm{~h}$ ). 
Figure 1

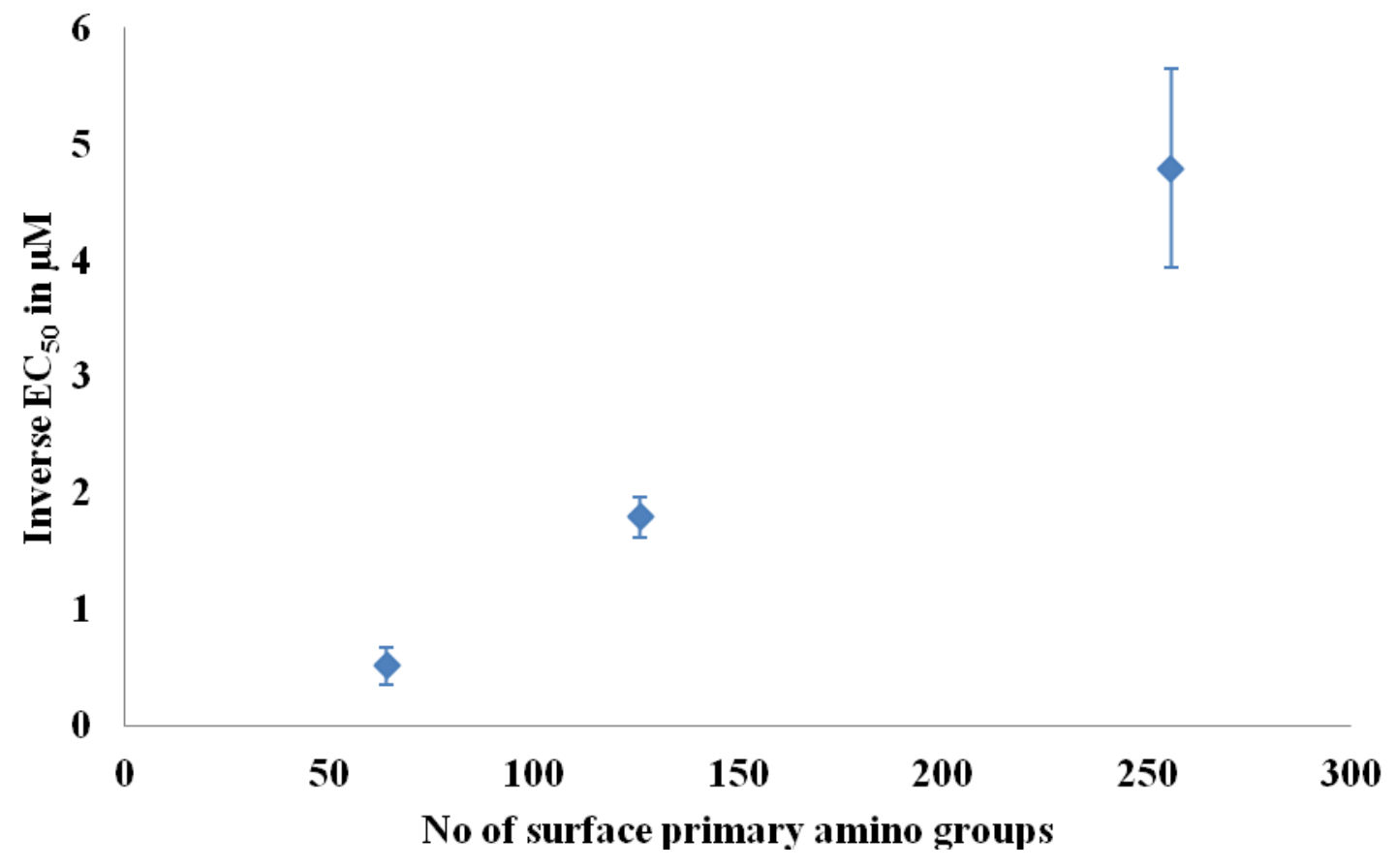


Figure 2
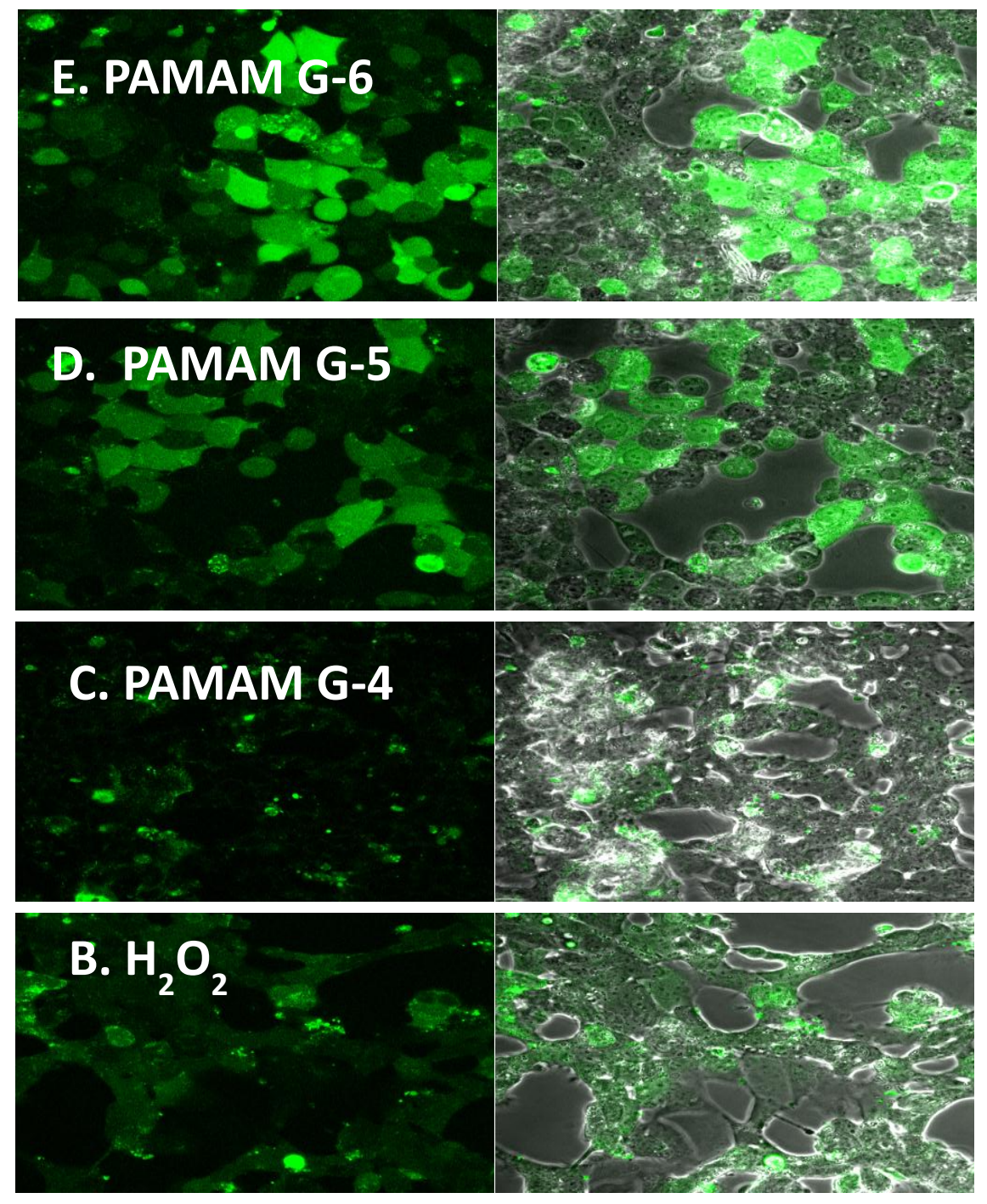

\section{A. Control}


Figure 3.

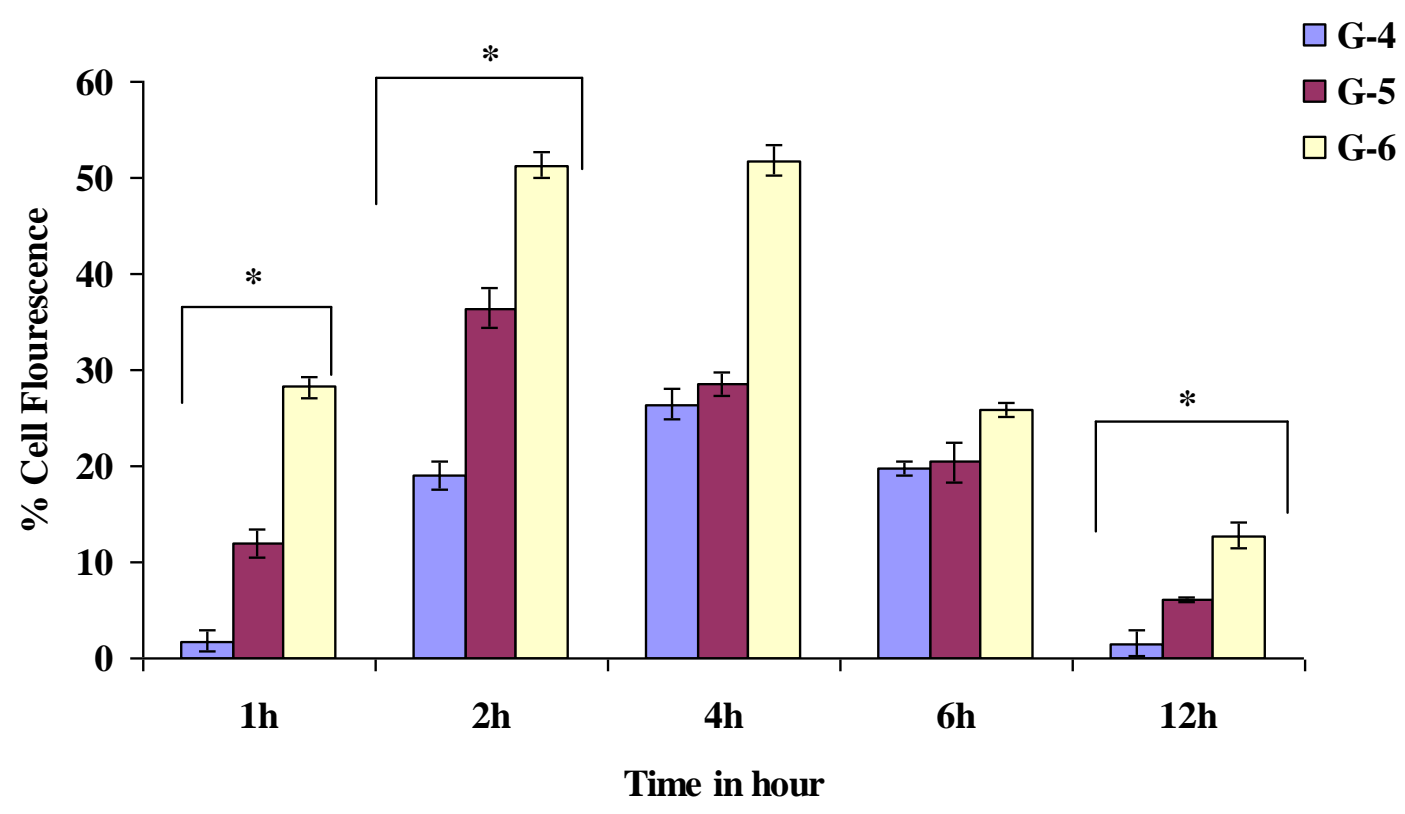


Figure 4.

A.

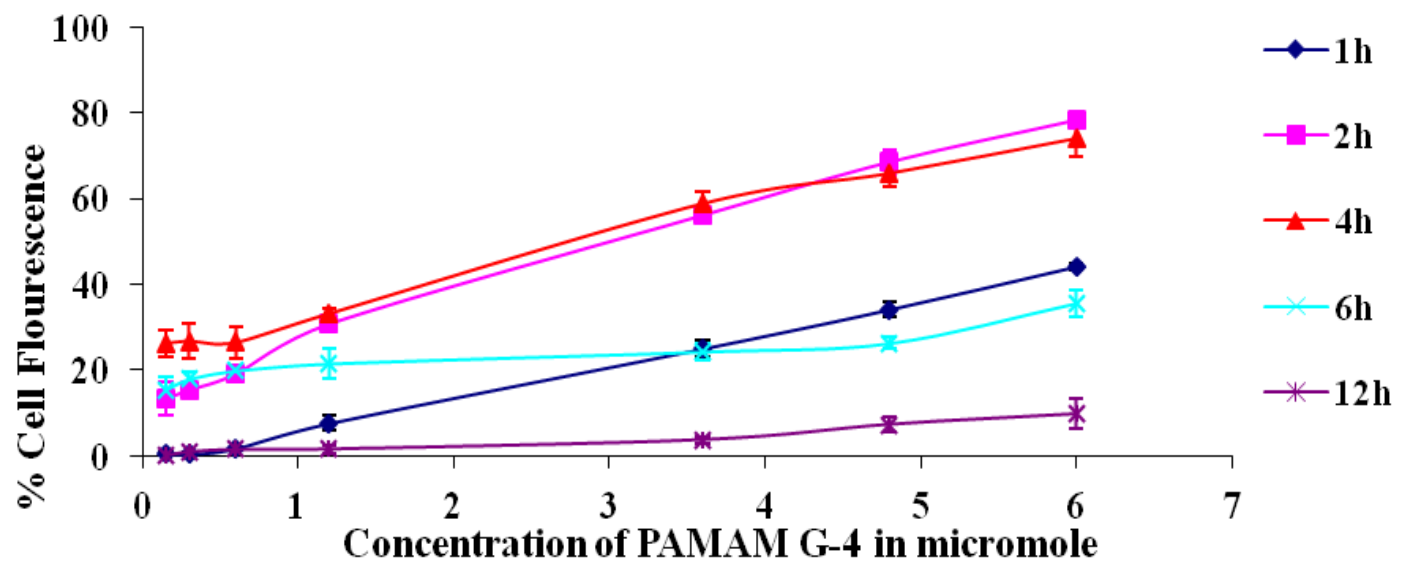

B.

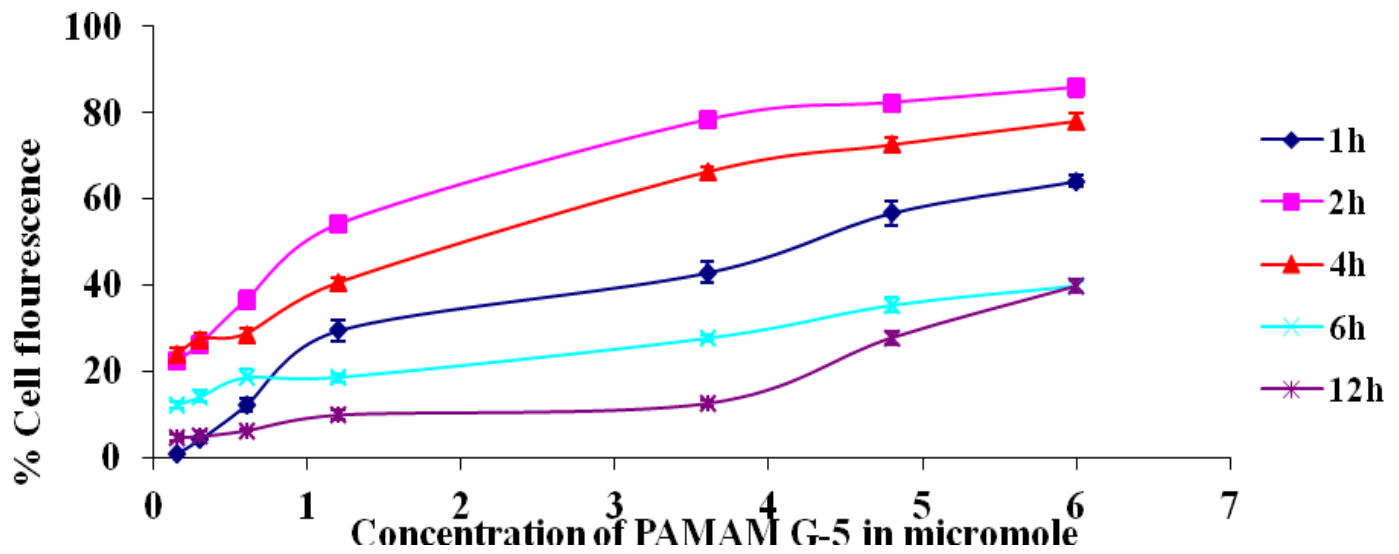

C.

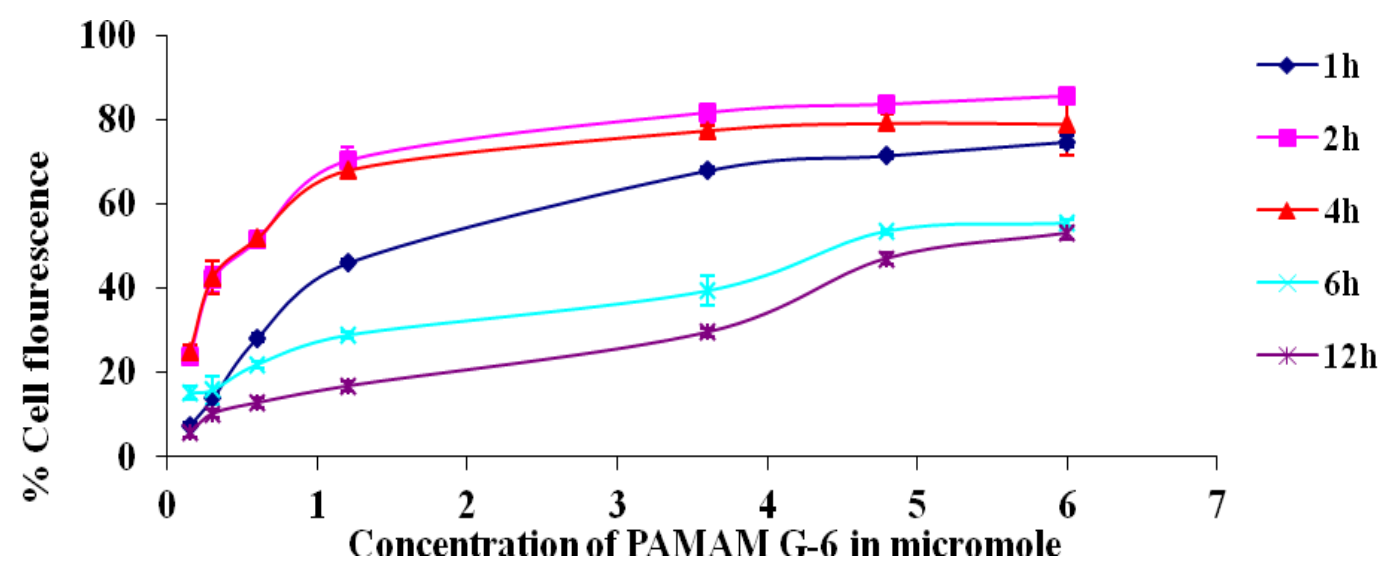


Figure 5

A.

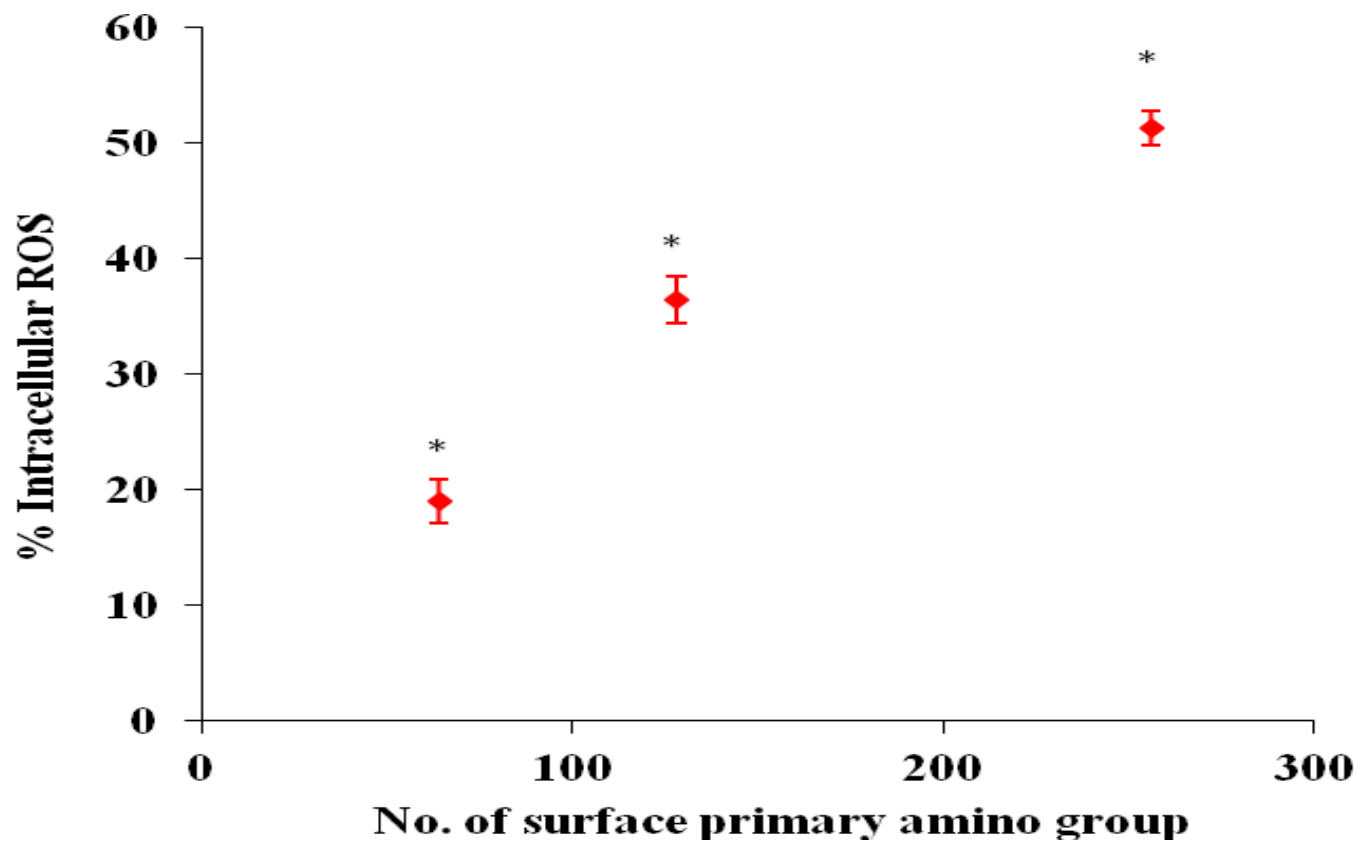

B.

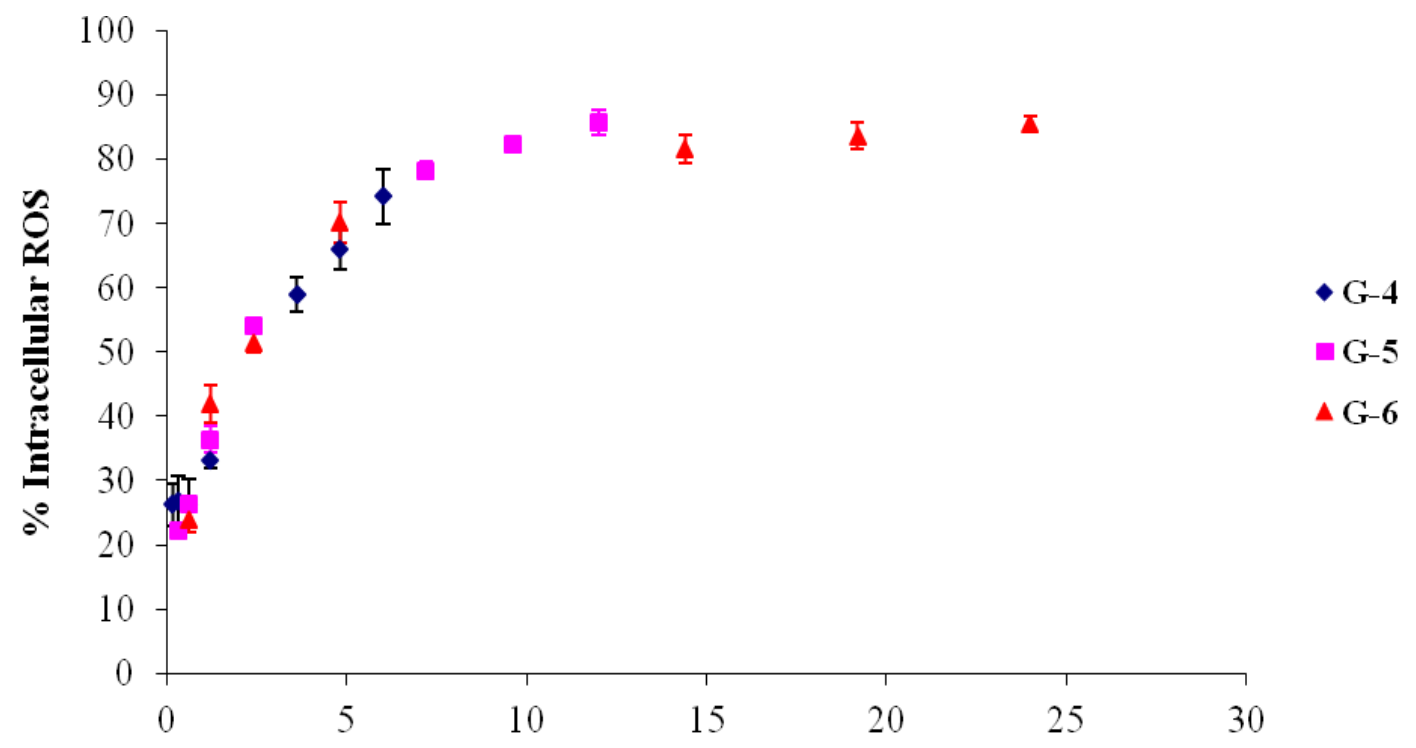

Molar dose $\mathrm{x}$ number of amino groups per PAMAM dendrimers 
Figure 6.
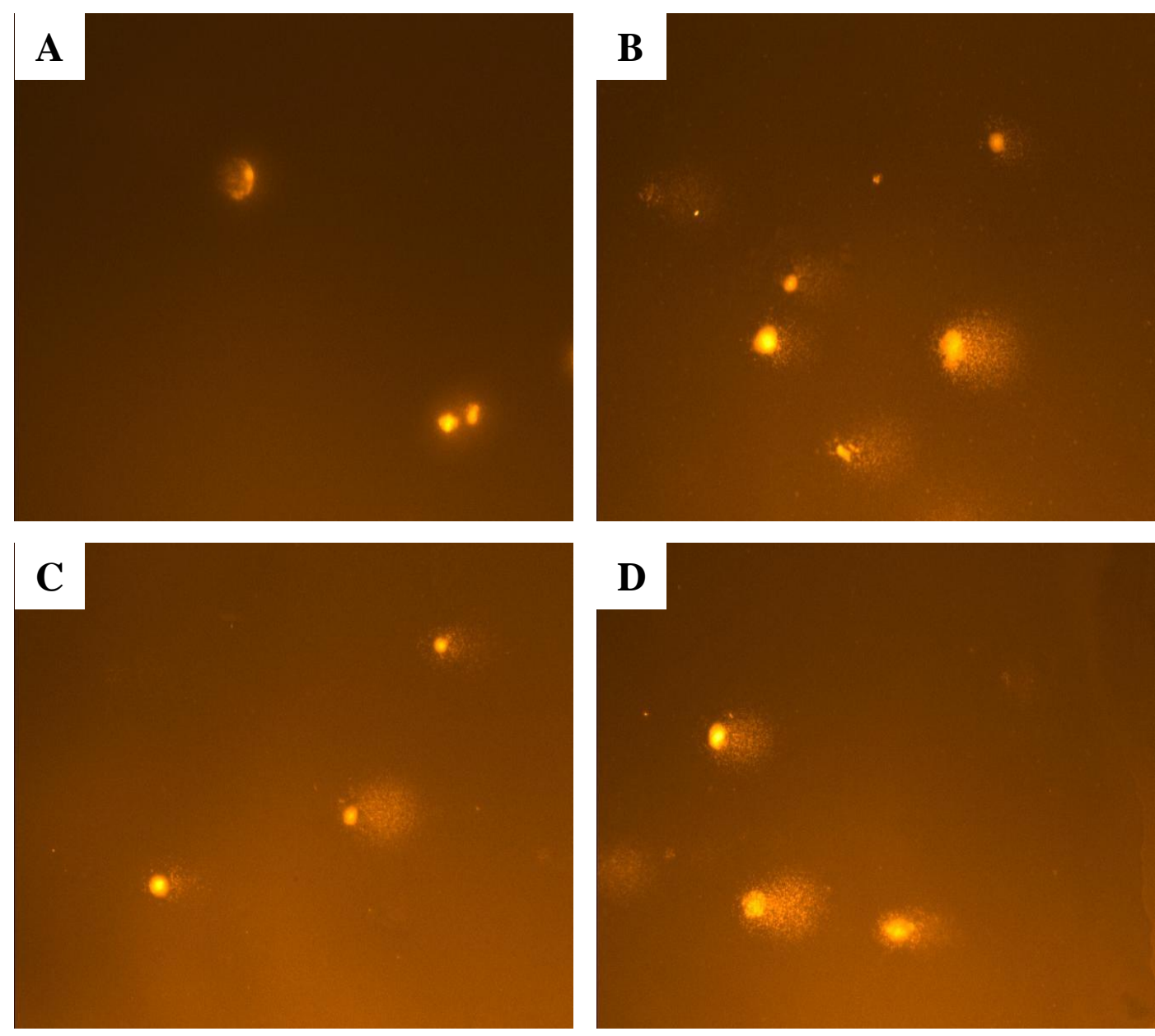

D

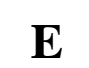


Figure 7.

A.

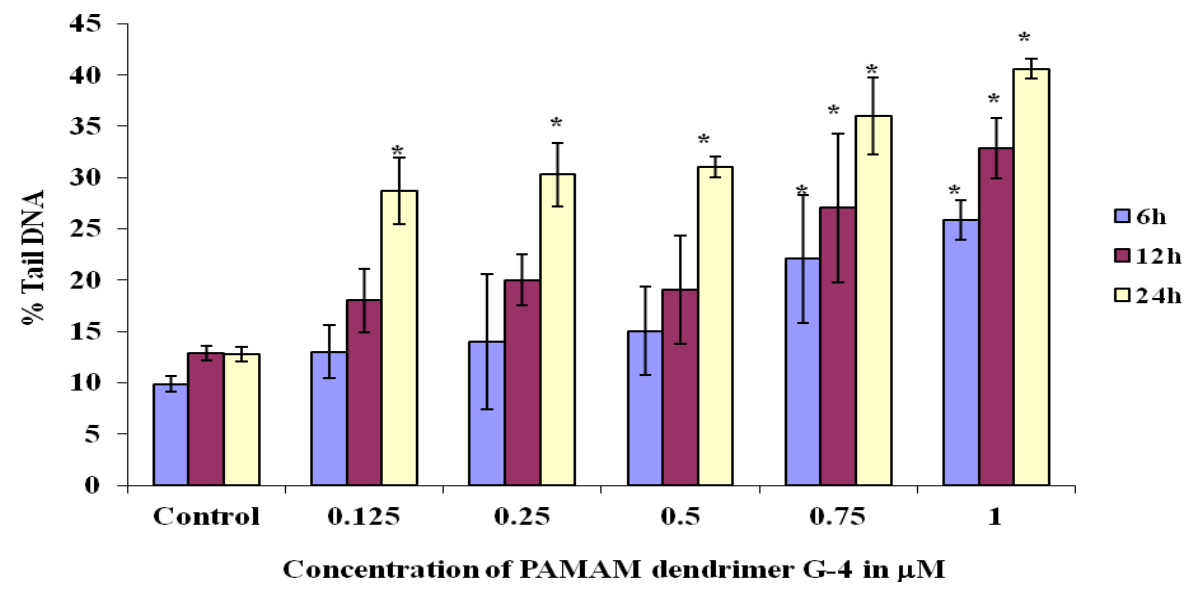

B.

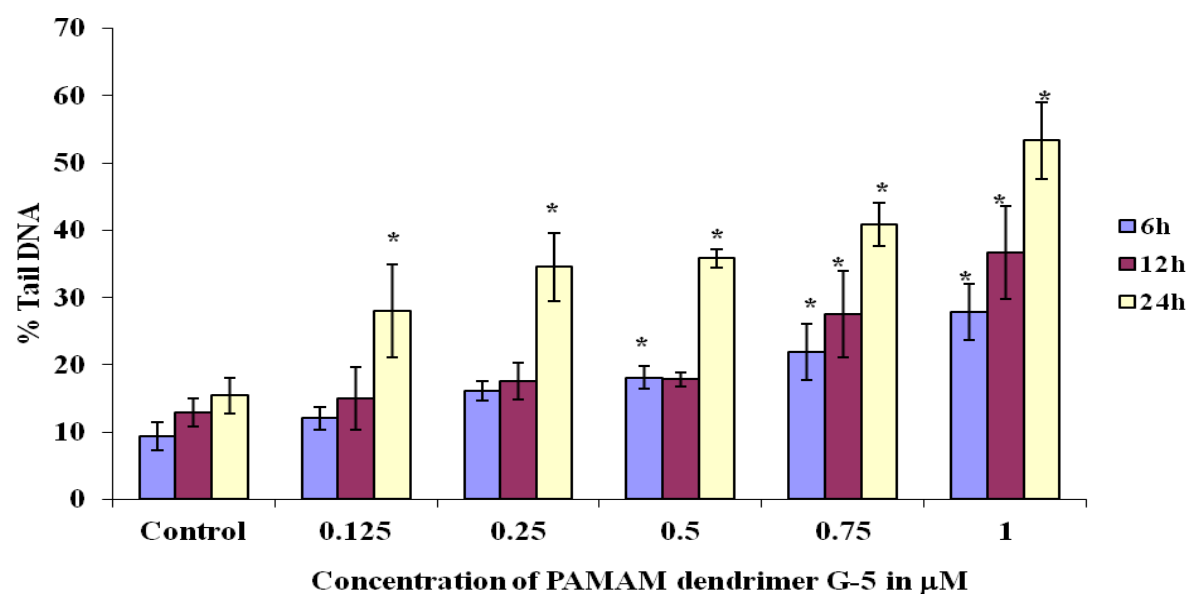

C.

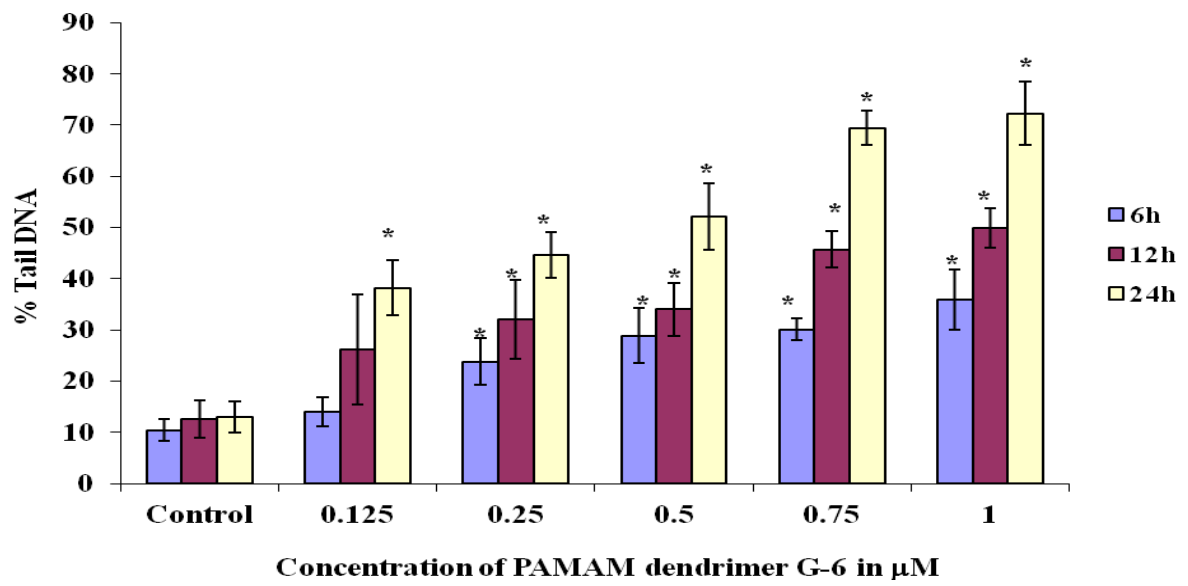


Figure 8

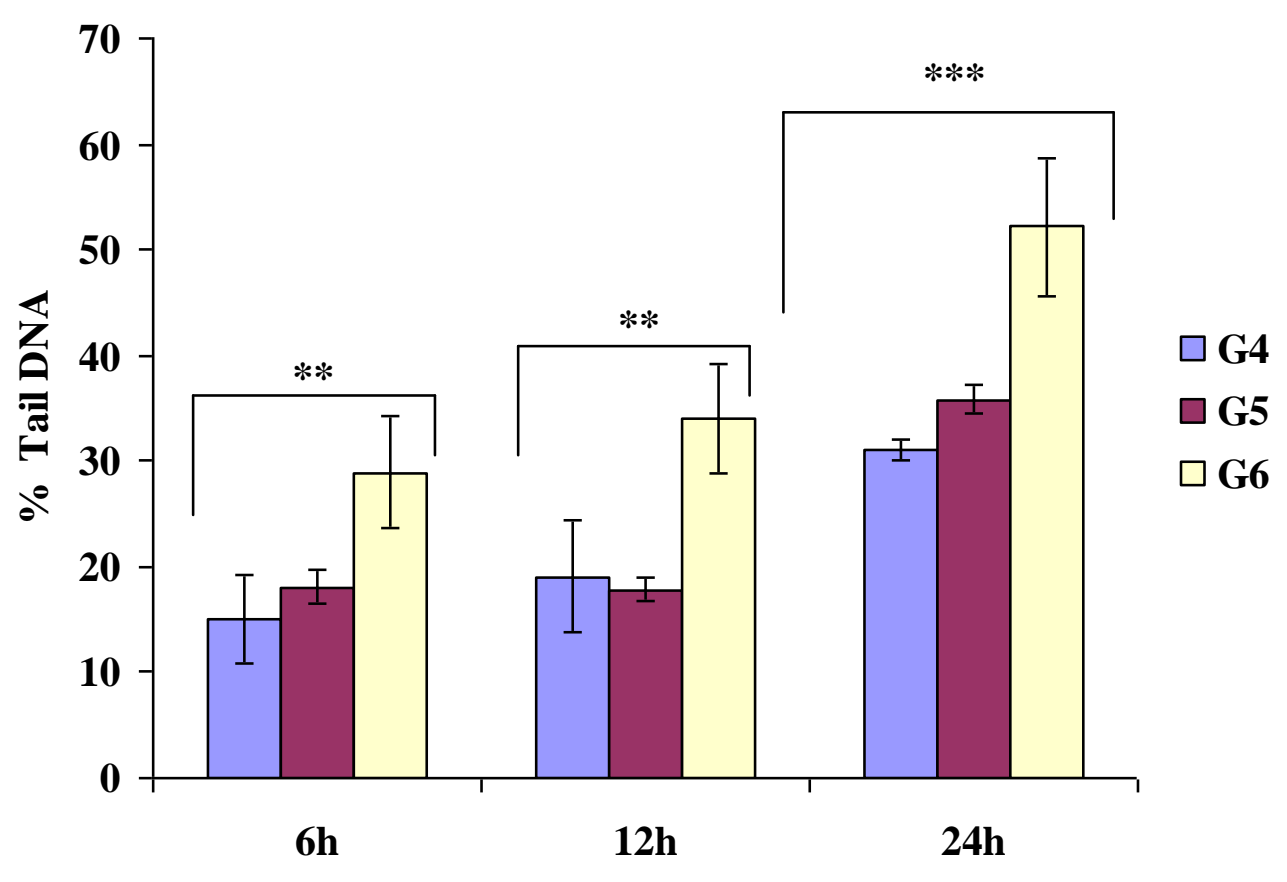

Time in hour 
Figure 9

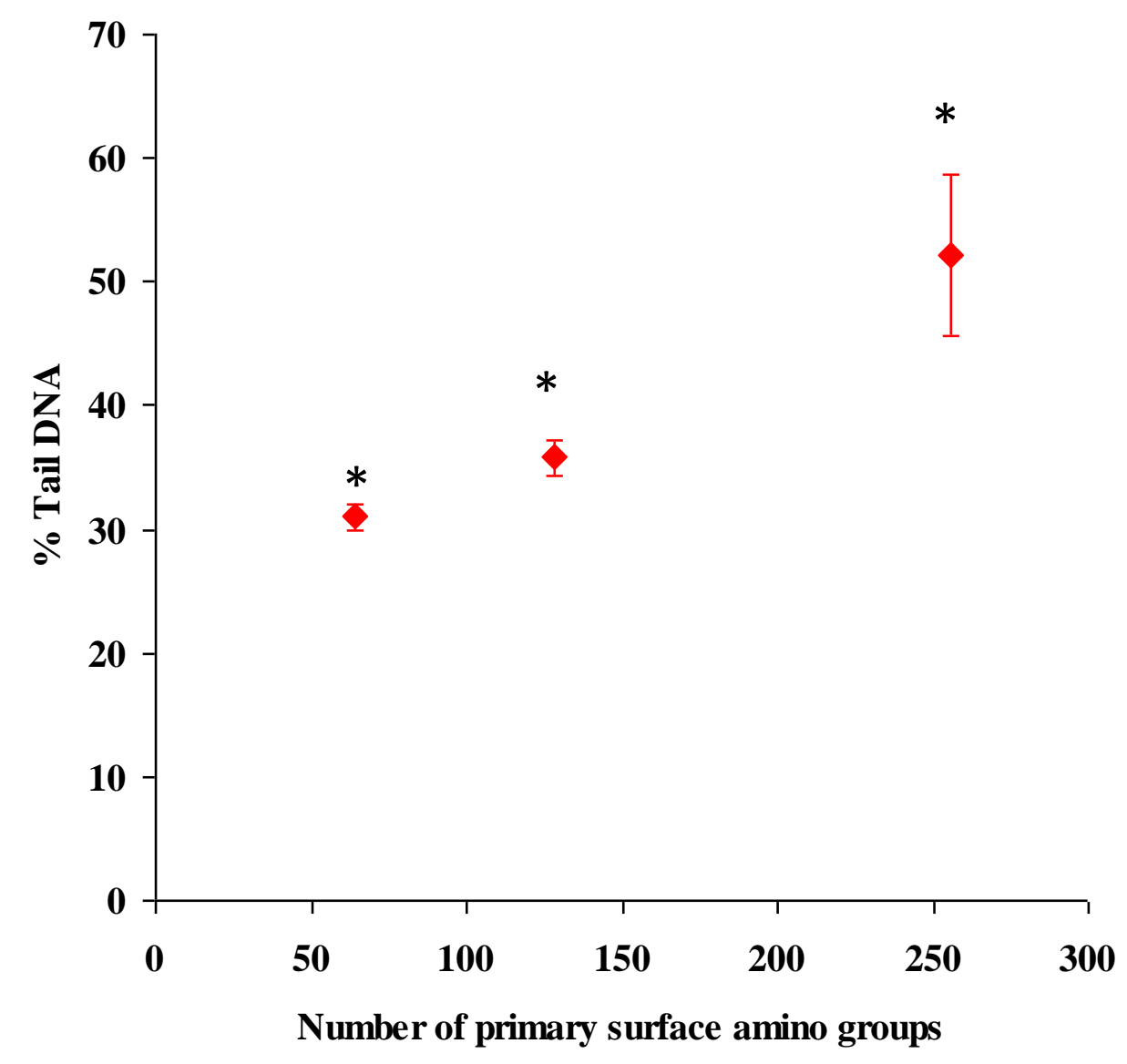


Figure 10.

A.

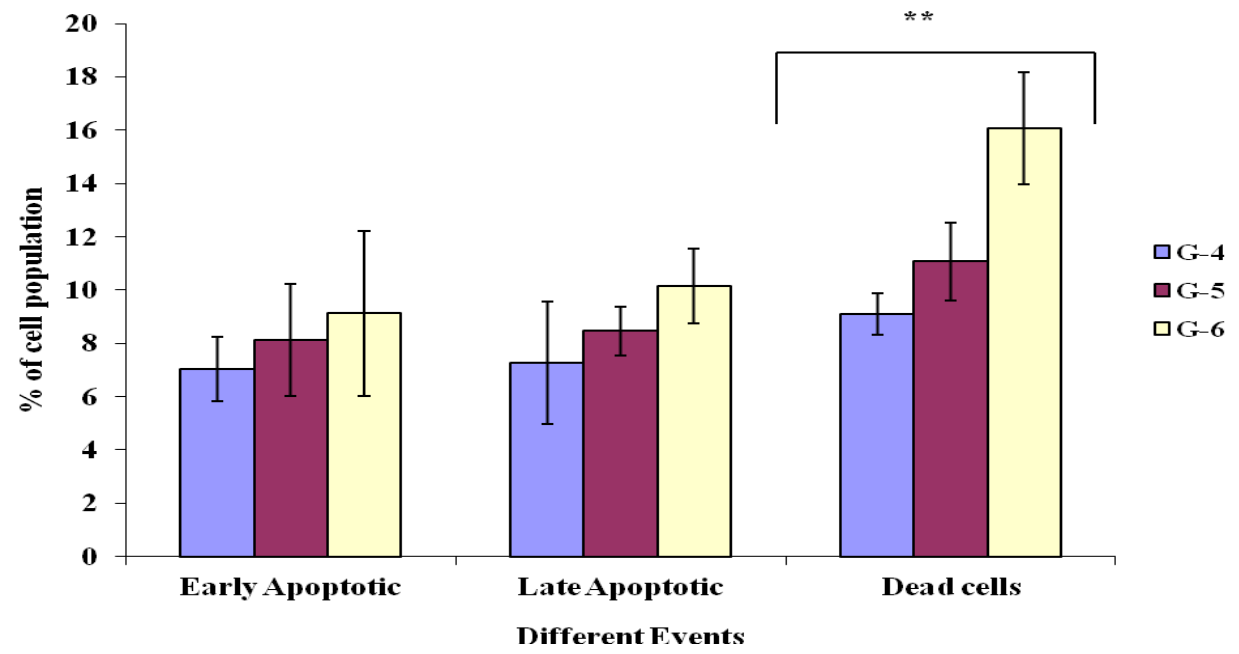

B.

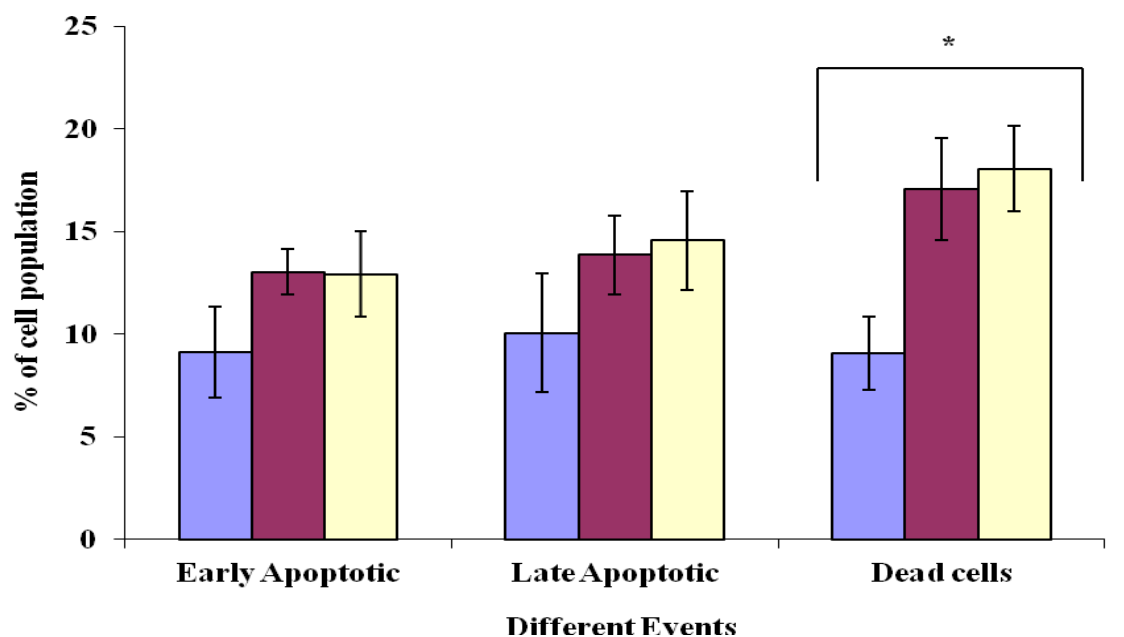

$\square$ G-4

口 G-5

ㅁ-6

C.

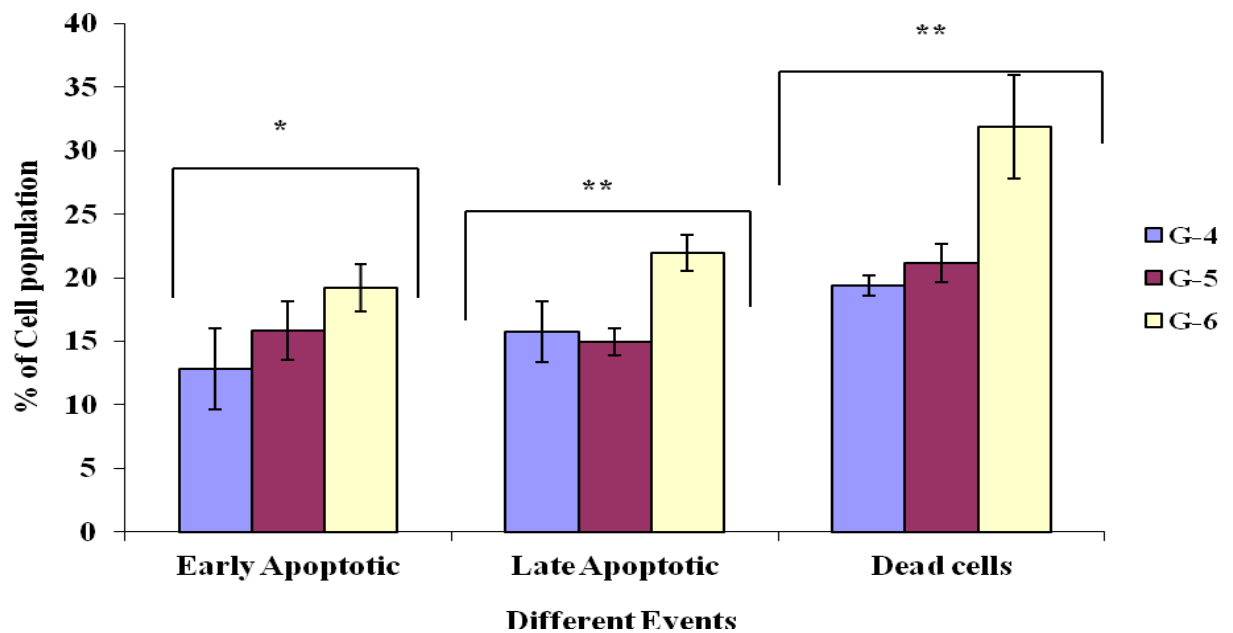


Figure 11

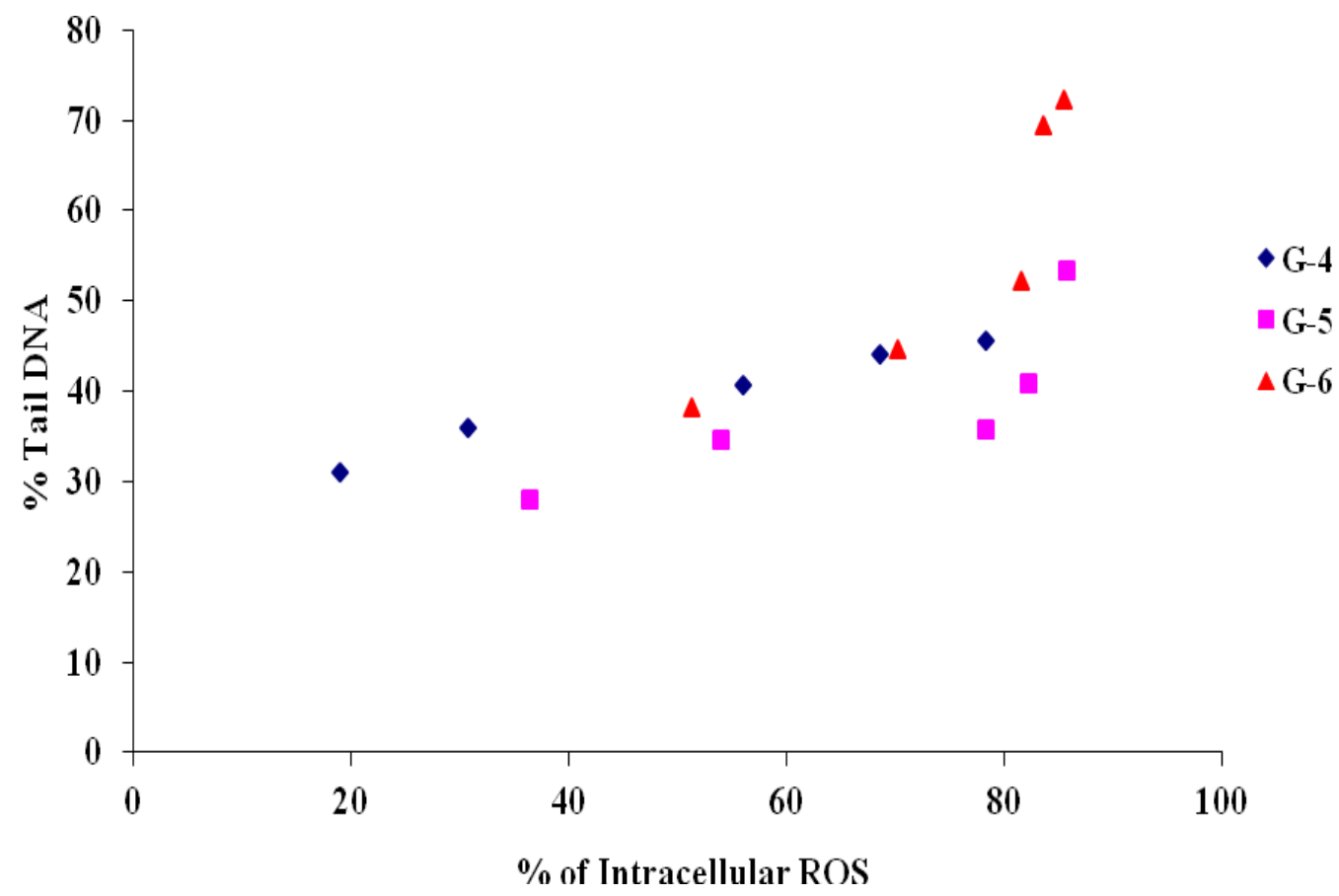




\section{Supporting information for genotoxicity paper}

1. Hydrodynamic diameter and zeta potential measurement

The particle size distributions and zeta potential of all three generations of dendrimers in the cell culture media were analyzed using Dynamic Light Scattering (DLS) (Malvern Instruments, UK). For a typical experiment, approximately $20 \mu \mathrm{M}$ concentration suspension of dendrimer nanoparticles in the Dulbecco's Modified Medium Nutrient Mixture/F-12 Ham [DMEM], with $5 \%$ foetal calf serum (FCS) supplement [PLHC-1] and were analysed at $20^{\circ} \mathrm{C}$.

2. Cytotoxicity assays.

For cytotoxicity tests, PLHC-1 cell suspension were seeded in 96 well microplates, using $100 \mu \mathrm{l}$ of the following cell suspension concentrations: $8 \mathrm{x}$ $10^{5}$ cells per ml for $24 \mathrm{~h}, 6 \times 10^{5}$ cells per ml for $48 \mathrm{~h}, 4 \times 10^{5}$ cells per ml for 72 and $2 \times 10^{5}$ cells per $\mathrm{ml}$ for the $96 \mathrm{~h}$ exposure. After $24 \mathrm{~h}$ of cell attachment, plates were washed with $100 \mu \mathrm{l} /$ well PBS and the cells were treated with increasing concentrations of each generation of dendrimer prepared in $5 \%$ FBS containing media. All incubations were performed at $30^{\circ} \mathrm{C}$. Six replicate wells were used for each control and test concentration per microplate.

The assays were carried out according to the manufacturer's instruction. Briefly, control media or test exposures were removed; the cells were rinsed with PBS and $100 \mu 1$ of $\mathrm{AB}$ medium (5\% v/v solution of $\mathrm{AB})$ prepared in fresh media (without FBS or supplements) were added to each well. After $3 \mathrm{~h}$ incubation, $\mathrm{AB}$ fluorescence was measured at the respective excitation and emission wavelength of $540 \mathrm{~nm}$ and $595 \mathrm{~nm}$ in a microplate reader (TECAN GENios, Grodig, Austria). 
Table S1: Hydrodynamic diameter and Zeta potential data of PAMAM dendrimers in PLHC-1 media.

\begin{tabular}{|l|l|l|l|}
\hline Experiments & PAMAM G-4 & PAMAM G-5 & PAMAM G-6 \\
\hline $\begin{array}{l}\text { Hydrodynamic } \\
\text { diameter (Size in } \\
\mathrm{nm})\end{array}$ & $6.6 \pm 0.2$ & $6.6 \pm 0.3$ & $11.5 \pm 0.3$ \\
\hline Zeta potential (mV) & $-2.8 \pm 1.1$ & $-2.1 \pm 0.9$ & $-2.2 \pm 0.4$ \\
\hline
\end{tabular}

Table S2: Levels of 8-OHdG formation in the PLHC-1 cells to PAMAM dendrimers exposure.

\begin{tabular}{|c|c|c|c|}
\hline & $\begin{array}{c}6 \mathrm{~h} \\
8-\mathrm{OHdG} \text { level in } \\
\mathrm{ng} / \mathrm{ml}\end{array}$ & $\begin{array}{c}12 \mathrm{~h} \\
8-O H d G \text { level in } \\
\mathrm{ng} / \mathrm{ml}\end{array}$ & $\begin{array}{c}24 \mathrm{~h} \\
8-\mathrm{OHdG} \text { level } \\
\mathrm{in} \mathrm{ng} / \mathrm{ml}\end{array}$ \\
\hline Control & $<0.125$ & $<0.125$ & $<0.125$ \\
\hline $\mathrm{H}_{2} \mathrm{O}_{2}$ & $0.6 \pm 0.3$ & $2.9 \pm 0.3$ & $15.7 \pm 0.3$ \\
\hline $\mathrm{G} 4$ & $<0.125$ & $<0.125$ & $<0.125$ \\
\hline $\mathrm{G} 5$ & $<0.125$ & $<0.125$ & $<0.125$ \\
\hline $\mathrm{G} 6$ & $<0.125$ & $<0.125$ & $<0.125$ \\
\hline
\end{tabular}


Figure S1.

A

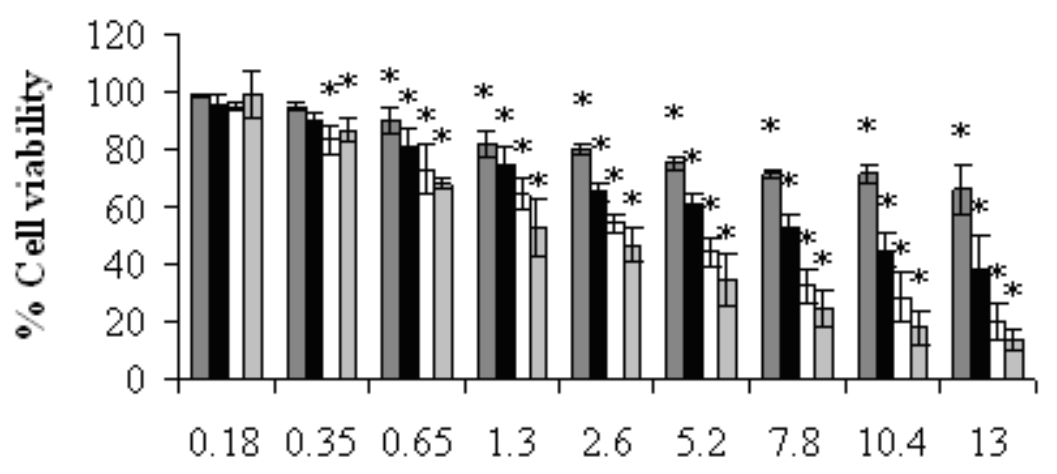

Concentration of Dendrimer in $\mu \mathrm{M}$

B

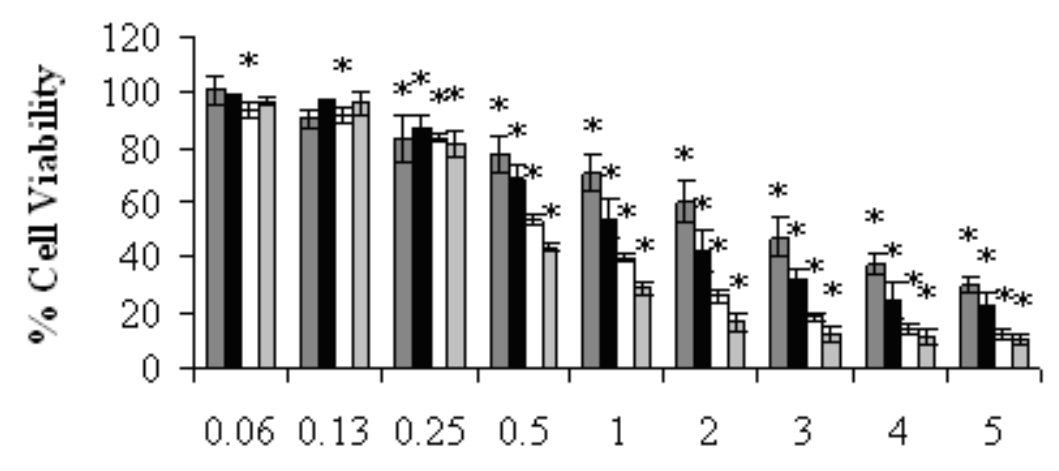

Concentration of Dendrimer in $\mu \mathrm{M}$

C

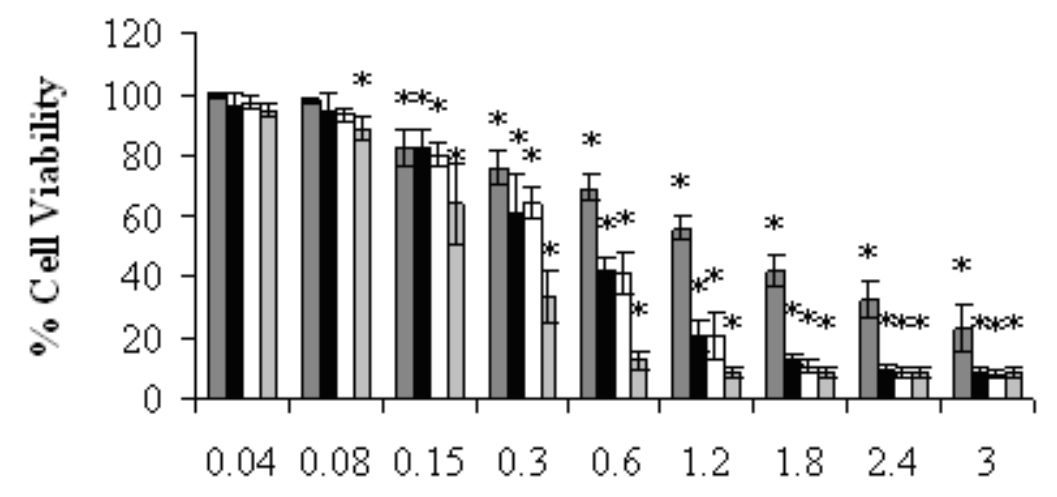

Concentration of dendrimer in $\mu \mathrm{M}$

Figure legends

Figure S1: Cytotoxicity of PAMAM dendrimer in PLHC-1 cells as quantified using the AB Assay. A, B and C represent G-4, G-5 and G-6 respectively. Data presented 
ares mean $\pm \mathrm{SD}(\mathrm{N}=3) . *$ Denotes significant difference from control $(p \leq 0.05) .24 \mathrm{~h}$

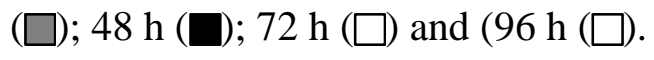

